\title{
The enzymology of mitochondrial fatty acid beta-oxidation and its application to follow-up analysis of positive neonatal screening results
}

\author{
Ronald J. A. Wanders • Jos P. N. Ruiter • \\ Lodewijk IJIst • Hans R. Waterham • Sander M. Houten
}

Received: 30 October 2009/Revised: 19 March 2010 / Accepted: 12 April 2010/Published online: 20 May 2010

(C) The Author(s) 2010. This article is published with open access at Springerlink.com

\begin{abstract}
Oxidation of fatty acids in mitochondria is a key physiological process in higher eukaryotes including humans. The importance of the mitochondrial betaoxidation system in humans is exemplified by the existence of a group of genetic diseases in man caused by an impairment in the mitochondrial oxidation of fatty acids. Identification of patients with a defect in mitochondrial beta-oxidation has long remained notoriously difficult, but the introduction of tandem-mass spectrometry in laboratories for genetic metabolic diseases has revolutionalized the field by allowing the rapid and sensitive analysis of acylcarnitines. Equally important is that much progress has been made with respect to the development of specific enzyme assays to identify the enzyme defect in patients subsequently followed by genetic analysis. In this review, we will describe the current state of knowledge in the field of fatty acid oxidation enzymology and its application to the follow-up analysis of positive neonatal screening results.
\end{abstract}

Communicated by: Verena Peters.

Competing interest: None declared.

Presented at: the Fulda-Symposium "Fatty Acid Oxidation: Clinical, Biochemical and Molecular Aspects”, 12-14 November 2008.

R. J. A. Wanders $(\bowtie) \cdot J$. P. N. Ruiter • L. IJlst •

H. R. Waterham $\cdot$ S. M. Houten

Laboratory Genetic Metabolic Diseases,

Departments of Clinical Chemistry and Pediatrics,

Emma Children's Hospital, Academic Medical Center,

University of Amsterdam,

Meibergdreef 9,

1105 AZ Amsterdam, The Netherlands

e-mail: r.j.wanders@amc.uva.nl

\section{Introduction}

Fatty acids (FAs) constitute an important source of energy in humans not only during fasting but also under well-fed conditions, since some organs, including the heart, show a marked preference for FAs at all times. Mitochondrial fatty acid oxidation (FAO) is the principal pathway for oxidation of FAs (Kunau et al. 1995), although FAs can also undergo alpha- and omega-oxidation (Wanders et al. 2003). The latter two pathways do not contribute much to the oxidation of FAs in terms of energy production in human beings and depend on beta-oxidation for further degradation of the FAs. Importantly, in higher eukaryotes including humans, beta-oxidation does not only occur in mitochondria but also in peroxisomes. Oxidation in the two organelles proceeds via a similar mechanism that involves four enzymatic steps in which an acyl-coenzyme A ester (acyl-CoA) undergoes subsequent steps of dehydrogenation, hydratation, another dehydrogenation, and finally thiolytic cleavage. Despite these similarities, there are major differences between the two systems in terms of the enzymes involved, their regulation, and the substrates handled by the two oxidation systems. Indeed, it is clearly established that the bulk of the dietary FAs including palmitic acid, oleic acid, and linoleic acid are beta-oxidized in mitochondria. Peroxisomes, however, play an equally indispensable role in whole cell fatty acid oxidation, by catalyzing the beta-oxidation of a range of FAs and fatty acid derivatives that are not handled by mitochondria, which include very-long-chain FAs, pristanic acid, and the bile acid intermediates di- and trihydroxycholestanoic acid (Wanders and Waterham 2006). The distinct physiological roles of the two beta-oxidation systems is exemplified by the differences in clinical signs and symptoms of patients affected by either a mitochondrial beta-oxidation defect (Rinaldo et al. 2002) or a peroxisomal 
beta-oxidation defect (Wanders and Waterham 2006). Table 1 lists the mitochondrial FAO-deficiencies currently known with relevant information on the enzyme defects and genes involved.

\section{Enzymology of the mitochondrial beta-oxidation system}

The FAs oxidized in mitochondria, may come from different sources including (1) the diet, (2) de novo synthesis, (3) release from adipose tissue, and (4) release from different intracellular sites, including the peroxisome and lysosome. Indeed, since peroxisomes are not able to degrade FAs to completion, they release the chainshortened FAs either as free FAs or as carnitine ester (Wanders and Waterham 2006), which are subsequently taken up by mitochondria for full oxidation to $\mathrm{CO}_{2}$ and $\mathrm{H}_{2} \mathrm{O}$. Hydrolysis of macro-molecules in lysosomes mediated for instance by the enzyme palmitoyl protein thioesterase (PPT) also yields FAs as one of the end products.

The generally accepted notion holds that FAs are rapidly activated to the corresponding CoA-esters by one of a variety of different acyl-CoA synthetases of the long-chain
acyl-CoA synthetase (LACS) and very-long-chain acylCoA synthetase (VLACS) subfamilies which reside in the plasma membrane, mitochondria, peroxisomes and endoplasmic reticulum (Mashek et al. 2004; Watkins 2008).

Short- and medium-chain FAs are activated in the mitochondrial matrix (Mashek et al. 2004). The acyl-CoA esters as such cannot traverse the mitochondrial inner membrane and require the carnitine shuttle for this purpose (McGarry and Brown 1997). Once inside the mitochondrion, the acyl-CoA esters can be beta-oxidized to completion, and the end product acetyl-CoA can be fully degraded to $\mathrm{CO}_{2}$ and $\mathrm{H}_{2} \mathrm{O}$ via the Krebs cycle which also involves the active participation of the mitochondrial oxidative phosphorylation system (Fig. 1).

\section{Diagnostics by enzymatic analysis of the enzymes involved in the carnitine cycle and mitochondrial acyl-CoA beta-oxidation}

In any patient suspected to suffer from a mitochondrial beta-oxidation defect, enzymatic analysis needs to be done to pinpoint the true underlying defect. In principle, there are two scenarios: the first scenario is identification of the

Table 1 Characteristics of the mitochondrial beta-oxidation deficiencies

\begin{tabular}{|c|c|c|c|c|c|c|}
\hline Deficiency & Gene & $\begin{array}{l}\text { Protein } \\
\text { (abbreviation) }\end{array}$ & $\begin{array}{l}\text { Gene } \\
\text { locus }\end{array}$ & $\begin{array}{l}\text { Defect } \\
\text { described }\end{array}$ & $\begin{array}{l}\text { Molecular defect } \\
\text { resolved }\end{array}$ & OMIM \\
\hline \multicolumn{7}{|l|}{ Cellular uptake of carnitine and fatty acids } \\
\hline Plasma membrane carnitine transporter & $S L C 22 A 5$ & OCTN2 & $5 \mathrm{q} 33.1$ & 1975 & 1998 & 212140 \\
\hline Long-chain fatty acid transporter & $?$ & $?$ & $?$ & 1998 & - & 600691 \\
\hline \multicolumn{7}{|l|}{ Mitochondrial carnitine cycle } \\
\hline Carnitine palmitoyltransferase 1 (liver form) & CPT1A & CPT1A & $11 \mathrm{q} 13$ & 1981 & 1998 & $\begin{array}{l}600528 \\
255120\end{array}$ \\
\hline Carnitine acylcarnitine translocase & SLC25A2 & CACT & $3 \mathrm{p} 21$ & 1992 & 1997 & 212138 \\
\hline Carnitine palmitoyltransferase 2 & $C P T 2$ & СРT2 & $1 \mathrm{p} 32$ & 1973 & 1992 & $\begin{array}{l}600649 \\
255110\end{array}$ \\
\hline \multicolumn{7}{|l|}{ Mitochondrial beta-oxidation system } \\
\hline Very-long-chain acyl-CoA dehydrogenase & $A C A D V L$ & VLCAD & $17 \mathrm{p} 11$ & 1993 & 1995 & 201475 \\
\hline Medium-chain acyl-CoA dehydrogenase & $A C A D M$ & MCAD & $1 \mathrm{p} 31$ & 1982 & 1990 & 201450 \\
\hline Short-chain acyl-CoA dehydrogenase & $A C A D S$ & SCAD & $12 \mathrm{q} 22$ & 1984 & 1990 & 201470 \\
\hline $\begin{array}{l}\text { Isolated long-chain 3-hydroxyacyl-CoA } \\
\text { dehydrogenase }\end{array}$ & HADHA & LCHAD & $2 \mathrm{p} 23$ & 1989 & 1994 & 600890 \\
\hline Isolated long-chain 3-ketothiolase & $H A D H B$ & LCKAT & $2 \mathrm{p} 23$ & 2006 & 2006 & 143450 \\
\hline \multirow[t]{2}{*}{ Complete mitochondrial trifunctional protein } & HADHA & LCHAD & $2 \mathrm{p} 23$ & 1992 & 1995 & 600890 \\
\hline & $H A D H B$ & LCKAT & $2 \mathrm{p} 23$ & 1992 & 1995 & 143450 \\
\hline Short-chain 3-hydroxyacyl-CoA dehydrogenase & $H A D H S C$ & SCHAD & $4 q 22$ & 2001 & 2001 & 601609 \\
\hline Medium-chain 3-ketoacyl-CoA thiolase & $A C A A 2$ & MCKAT & & 1997 & - & 602199 \\
\hline ETF dehydrogenase & ETFDH & ETFDH & $4 q 32$ & 1985 & 1993 & 231675 \\
\hline ETF-alpha & ETFA & $\mathrm{ETF} \alpha$ & $15 \mathrm{q} 23$ & 1986 & 1991 & 608053 \\
\hline ETF-beta & $E T F B$ & ETF $\beta$ & $19 \mathrm{q} 13$ & 1991 & 1994 & 130410 \\
\hline 2,4-dienoyl-CoA reductase & DECRI & DECR1 & $8 \mathrm{q} 21$ & 1990 & - & 222745 \\
\hline
\end{tabular}


Fig. 1 Schematic representation of the mitochondrial fatty acid beta-oxidation pathway. The pathway starts with the uptake of FAs and carnitine from the plasma compartment into the cell, followed by the transport of acyl-CoA esters into the mitochondria via the carnitine cycle and the actual stepwise degradation of acyl-CoAs via the beta-oxidation spiral with acetyl-CoA units as end product, which can either be converted into ketone bodies or combusted in the citric acid cycle to $\mathrm{CO}_{2}$ and $\mathrm{H}_{2} \mathrm{O}$

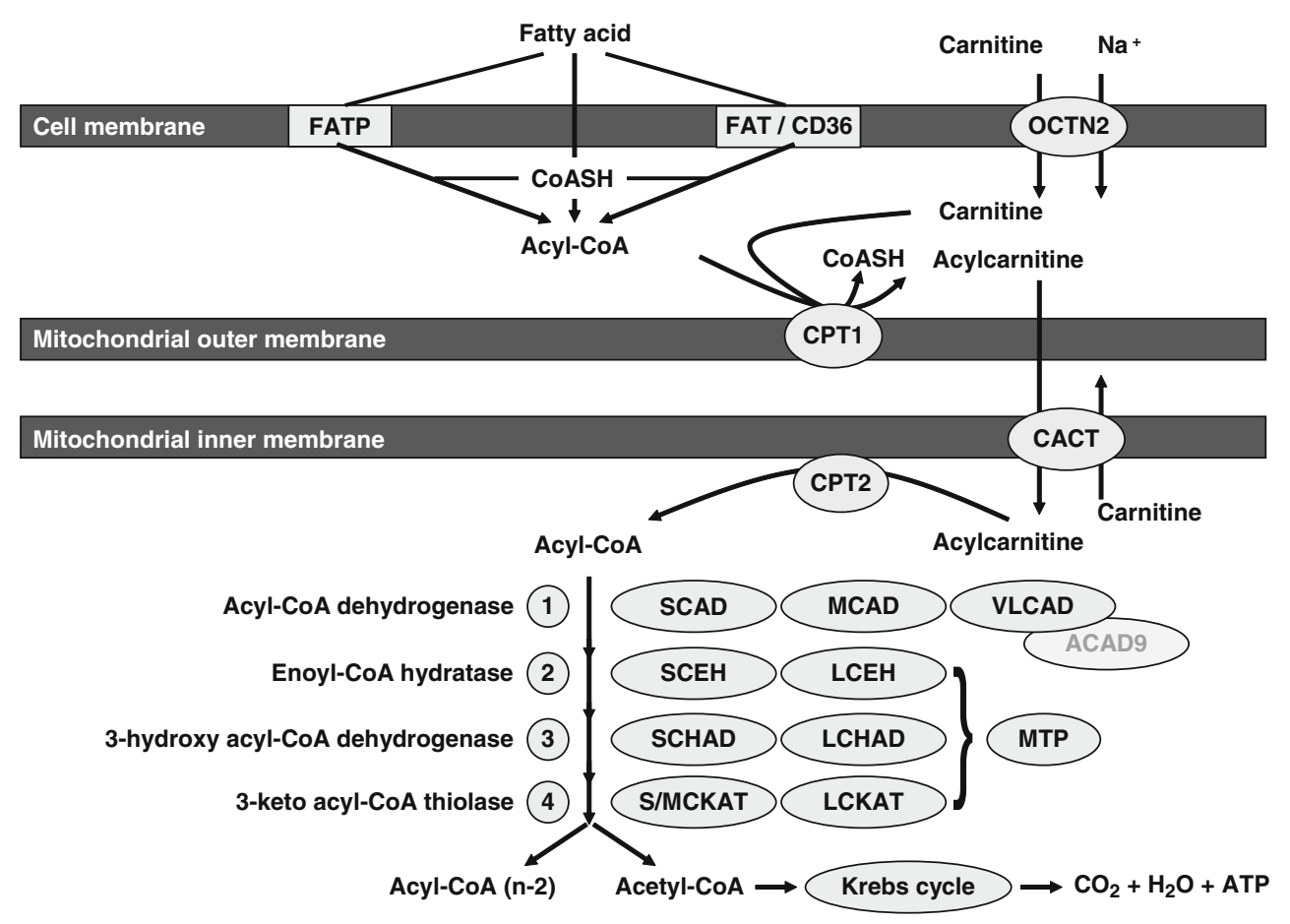

patient by an abnormal acylcarnitine profile in neonatal screening, the second is identification based on clinical signs and symptoms in combination with a characteristic acylcarnitine profile. Indeed, most of the currently identified mitochondrial beta-oxidation deficiencies are associated with distinct acylcarnitine profiles in plasma, which are different for each of the individual betaoxidation defects (Fig. 2). The only exception to this rule is CACT- versus CPT2-deficiency, which have identical acylcarnitine profiles. In all other cases, the acylcarnitine profiles usually suggest directly which step in the mitochondrial beta-oxidation system is defective (Fig. 2).

In order to rapidly identify the enzyme defect in patients after the finding of an abnormal acylcarnitine profile, we have set up enzyme activity measurements for CPT1, CACT, CPT2, VLCAD, MCAD, SCAD, LCHAD/MTP, and SCHAD in lymphocytes. This is especially relevant since existing neonatal screening programs have been extended in many countries around the world including the Netherlands and now include many of the mitochondrial beta-oxidation deficiencies. We will now discuss the carnitine cycle plus the actual beta-oxidation machinery in some detail including the enzymes involved with particular emphasis on the different enzyme assays currently in use for patient diagnostics. Special attention will be given to the enzyme assays developed in our own laboratory (see Table 2 for details on each of these enzyme assays).

\section{The mitochondrial carnitine cycle}

The mitochondrial carnitine cycle involves the concerted action of three distinct proteins including carnitine palmitoyltransferase 1 (CPT1), the mitochondrial carnitine/ acylcarnitine carrier (CACT), and carnitine palmitoyl transferase 2 (CPT2). All three proteins are membranebound, but there are notable differences. Indeed, CPT1 and CACT, but not CPT2, are truly integral membrane proteins with two and six transmembrane elements, respectively, with CPT1 being localized in the mitochondrial outer membrane and CACT in the mitochondrial inner membrane. CPT2 is loosely associated with the inner face of the mitochondrial inner membrane (Fig. 1).

CPT1 is the only enzyme of the mitochondrial fatty acid oxidation system that is known to exist in tissuespecific isoforms. The genes for liver-specific L-CPT1 and muscle specific M-CPT1 are on chromosomes $11 \mathrm{q} 13$ and 22q13.3, respectively, and each of the two genes encodes a $88-\mathrm{kDa}$ polypeptide with $63 \%$ identity. They differ in kinetic properties such as inhibitor constants for malonyl-CoA (McGarry and Brown 1997) and the $\mathrm{K}_{\mathrm{m}}$ for L-carnitine.

CACT is a homo-dimer of two $33-\mathrm{kDa}$ polypeptides, and is required for the transport of acylcarnitines (formed by CPT1) into the mitochondrion in exchange for free carnitine. The carnitine cycle is completed by CPT2 that reconverts the acylcarnitine back into the corresponding acyl-CoA, which is then substrate for the 


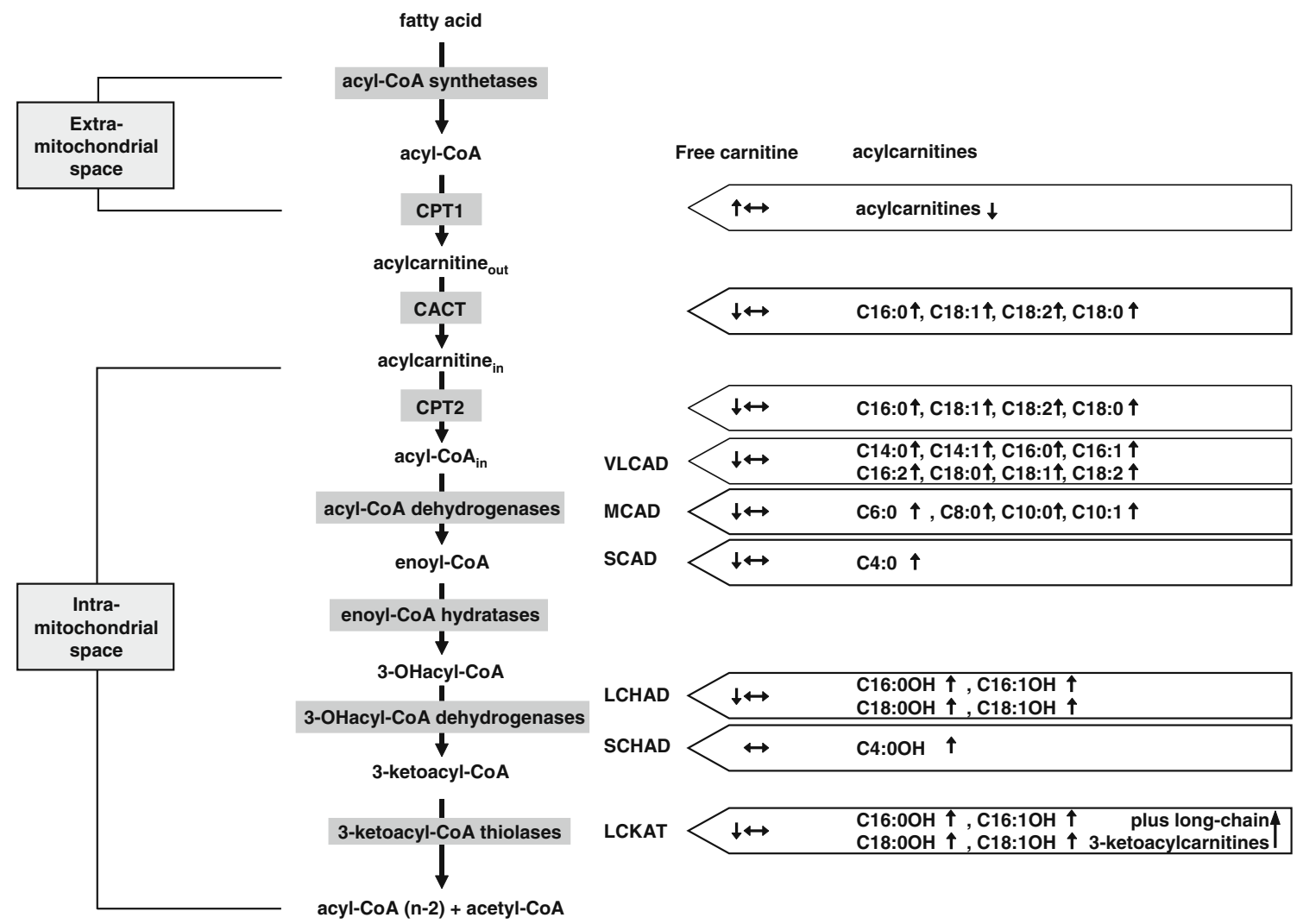

Fig. 2 Overview of the different mitochondrial fatty acid beta-oxidation deficiencies and the plasma acylcarnitine abnormalities identified in each of them

beta-oxidation system. It should be noted that CACT also accepts and transports short-chain acylcarnitines, such as acetylcarnitine and propionylcarnitine produced in peroxisomes (Wanders and Waterham 2006). Conversion of these two carnitine esters into acetyl-CoA and propionyl-CoA is not mediated by CPT2 but by the shortchain-specific enzyme carnitine acetyltransferase (CRAT). Interestingly, the carnitine cycle may also work in the reverse direction, which allows the export of acyl-CoA esters in the form of an acylcarnitine ester to the extramitochondrial space and subsequently into the extracellular space (Ventura et al. 1998).

\section{Enzymatic analysis of the carnitine cycle}

\section{$C P T 1$}

CPT1 catalyses the following reaction:

acyl-CoA + carnitine $\rightarrow$ acylcarnitine + CoASH.

Currently, only deficiencies of liver CPT1 have been reported. Fortunately, this CPT1 isoform is expressed in fibroblasts and lymphocytes. In principle, there are several ways to measure the activity of CPT1. A frequently used method involves incubation of freshly prepared tissue homogenates (Demaugre et al. 1988), isolated mitochondria, or selectively permeabilized cells (Schaefer et al. 1997) in a medium containing palmitoyl-CoA plus $\left[{ }^{14} \mathrm{C}\right]-$ labeled carnitine, followed by extraction of the $\left[{ }^{14} \mathrm{C}\right]$ labeled acylcarnitine using water-saturated butanol at the end of the incubation period. Incubations are usually performed in the presence and absence of malonyl-CoA $(>100 \mu \mathrm{mol} / \mathrm{L})$ and the malonyl-CoA-inhibitable activity is taken to represent true CPT1-activity. We have been using this method to determine the activity of CPT1 in cultured skin fibroblasts using digitonin to permeabilize the plasma membrane for quite a few years. Recently, however, we came across some serious pitfalls of this assay, one being the fact that the acylcarnitine produced by CPT1 turned out to undergo appreciable further oxidation (van Vlies et al. 2007). The implication of this finding was that the activity of CPT1 had been underestimated considerably. We have studied this phenomenon in detail and have found out that this problem could simply be overcome by addition of $\mathrm{KCN}$, an inhibitor of cytochrome $\mathrm{C}$ oxidase and thereby of the 
Table 2 Enzymatic analysis of the different mitochondrial fatty acid beta-oxidation enzymes and the experimental conditions used in our laboratory for each of these enzymes

\begin{tabular}{|c|c|c|c|c|}
\hline $\begin{array}{l}\text { Enzyme/ } \\
\text { transporter }\end{array}$ & $\begin{array}{l}\text { Assay } \\
\text { medium }\end{array}$ & $\begin{array}{l}\text { Incubation } \\
\text { period and } \\
\text { temperature }\end{array}$ & $\begin{array}{l}\text { Method of } \\
\text { analysis }\end{array}$ & Reference \\
\hline CPT1 & $\begin{array}{l}150 \mathrm{mmol} / \mathrm{L} \mathrm{KCl}, 25 \mathrm{mmol} / \mathrm{L} \text { Tris, } 2 \mathrm{mmol} / \mathrm{L} \\
\mathrm{EDTA}, 20 \mathrm{mmol} / \mathrm{L} \text { potassium phosphate, } \\
1 \mathrm{mg} / \mathrm{mL} \text { bovine serum albumin, } 4.5 \mathrm{mmol} / \mathrm{L} \\
\mathrm{GSH}, 5 \mathrm{mmol} / \mathrm{L} \mathrm{KCN}, 50 \mu \mathrm{g} / \mathrm{mL} \text { digitonin, } \\
0.5 \mathrm{mmol} / \mathrm{L} \text { carnitine, } \mathrm{pH}=7.0 \text {, plus } 25 \\
\mu \mathrm{mol} / \mathrm{L}\left[\mathrm{U}-{ }^{13} \mathrm{C}\right] \text {-palmitoyl-CoA }\end{array}$ & $10 \mathrm{~min}, 37^{\circ} \mathrm{C}$ & Tandem-MS & $\begin{array}{l}\text { (van Vlies } \\
\text { et al. 2007) }\end{array}$ \\
\hline CACT & $\begin{array}{l}150 \mathrm{mmol} / \mathrm{L} \mathrm{KCl}, 25 \mathrm{mmol} / \mathrm{L} \text { Tris- } \mathrm{HCl}, 2.0 \\
\mathrm{mmol} / \mathrm{L} \text { EDTA, } 10 \mathrm{mmol} / \mathrm{L} \text { potassium } \\
\text { phosphate, } 10 \mathrm{mg} / \mathrm{mL} \text { bovine serum albumin, } \\
40 \mu \mathrm{g} / \mathrm{mL} \text { digitonin, } \mathrm{pH}=7.4 \text { plus } 0.1 \mathrm{mmol} / \mathrm{L} \\
\text { acetylcarntinine and }\left[1-{ }^{14} \mathrm{C}\right] \text {-acetylcarnitine }\end{array}$ & $30 \mathrm{~min}, 25^{\circ} \mathrm{C}$ & $\begin{array}{l}\text { Radiometry } \\
\left({ }^{14} \mathrm{CO}_{2} \text { release }\right)\end{array}$ & $\begin{array}{l}\text { (IJlst et al. } \\
\text { 2001) }\end{array}$ \\
\hline СРT2 & $\begin{array}{l}100 \mathrm{mmol} / \mathrm{L} \text { Tris- } \mathrm{HCl}, 120 \mathrm{mmol} / \mathrm{L} \mathrm{KCl}, 5 \\
\mathrm{mmol} / \mathrm{L} \mathrm{GSH}, 8 \mathrm{mmol} / \mathrm{L} \mathrm{CoASH}, 2 \mathrm{mmol} / \mathrm{L} \\
\text { palmitoyl-carnitine, } 0.2 \%(\mathrm{w} / \mathrm{v}) \text { Triton X-100, } \\
\mathrm{pH}=7.0\end{array}$ & $20 \mathrm{~min}, 37^{\circ} \mathrm{C}$ & HPLC-UV & $\begin{array}{l}\text { To be } \\
\text { published }\end{array}$ \\
\hline VLCAD & $\begin{array}{l}125 \mathrm{mmol} / \mathrm{L} \text { Tris- } \mathrm{HCl}, 0.4 \mathrm{mmol} / \mathrm{L} \text { ferricenium } \\
\text { hexa-fluorophosphate, } 0.25 \mathrm{mmol} / \mathrm{L} \text { palmitoyl- } \\
\text { CoA, pH } 8.0\end{array}$ & $5 \mathrm{~min}, 37^{\circ} \mathrm{C}$ & HPLC-UV & $\begin{array}{l}\text { To be } \\
\text { published }\end{array}$ \\
\hline MCAD & $\begin{array}{l}200 \mathrm{mmol} / \mathrm{L} \text { Tris-HCl, } 0.22 \mathrm{mmol} / \mathrm{L} 3- \\
\text { phenylpropionyl-CoA, } 0.4 \mathrm{mmol} / \mathrm{L} \\
\text { ferricenium hexafluorophosphate, } \mathrm{pH}=8.0\end{array}$ & $10 \mathrm{~min}, 37^{\circ} \mathrm{C}$ & HPLC-UV & $\begin{array}{l}\text { To be } \\
\text { published }\end{array}$ \\
\hline LCHAD & $\begin{array}{l}100 \mathrm{mmol} / \mathrm{L} \text { potassium phosphate, } 50 \mathrm{mmol} / \mathrm{L} \\
\mathrm{MOPS}, 0.1 \mathrm{mmol} / \mathrm{L} \text { DTT, } 0.1 \%(\mathrm{w} / \mathrm{v}) \text { Triton } \\
\mathrm{X}-100,0.15 \mathrm{mmol} / \mathrm{L} \mathrm{NADH}, 5 \mathrm{mmol} / \mathrm{L} \\
\text { N-ethylmaleimide (if added), } \mathrm{pH}=6.16, \\
\text { plus } 50 \mu \mathrm{mol} / \mathrm{L} \text { 3-ketopalmitoyl-CoA }\end{array}$ & $\begin{array}{l}\text { Continuous } \\
\text { assay, } 37^{\circ} \mathrm{C}\end{array}$ & $\begin{array}{l}\text { Spectrophotometry } \\
(340 \mathrm{~nm})\end{array}$ & $\begin{array}{l}\text { (Wanders } \\
\text { et al. 1990) }\end{array}$ \\
\hline LCTH & $\begin{array}{l}100 \mathrm{mmol} / \mathrm{L} \text { Tris- } \mathrm{HCl}, 10 \mathrm{mmol} / \mathrm{L} \mathrm{MgCl}_{2} \\
50 \mu \mathrm{mol} / \mathrm{L} \text { CoASH, } \mathrm{pH}=8.05 \text {, plus } 50 \\
\mu \mathrm{mol} / \mathrm{L} \text { 3-ketopalmitoyl-CoA }\end{array}$ & $\begin{array}{l}\text { Continuous } \\
\text { assay, } 37^{\circ} \mathrm{C}\end{array}$ & $\begin{array}{l}\text { Spectrophotometry } \\
(303 \mathrm{~nm})\end{array}$ & $\begin{array}{l}\text { (Wanders } \\
\text { et al. 1990) }\end{array}$ \\
\hline SCHAD & $\begin{array}{l}100 \mathrm{mmol} / \mathrm{L} \text { potassium phosphate, } 50 \mathrm{mmol} / \mathrm{L} \\
\text { MOPS, } 0.1 \mathrm{mmol} / \mathrm{L} \text { DTT, } 0.1 \%(\mathrm{w} / \mathrm{v}) \text { Triton } \\
\mathrm{X}-100,0.15 \mathrm{mmol} / \mathrm{L} \mathrm{NADH}, 5 \mathrm{mmol} / \mathrm{L} \\
\text { N-ethylmaleimide (if added), } \mathrm{pH}=6.16, \\
\text { plus } 50 \mu \mathrm{mol} / \mathrm{L} \text { acetoacetyl-CoA }\end{array}$ & $\begin{array}{l}\text { Continuous } \\
\text { assay, } 37^{\circ} \mathrm{C}\end{array}$ & $\begin{array}{l}\text { Spectrophotometry } \\
(340 \mathrm{~nm})\end{array}$ & $\begin{array}{l}\text { (Wanders } \\
\text { et al. 1990) }\end{array}$ \\
\hline
\end{tabular}

mitochondrial oxidative phosphorylation system. Addition of $\mathrm{KCN}$ blocked further oxidation of palmitoylcarnitine completely (van Vlies et al. 2007). With KCN present in the assay medium CPT1 activities as measured in fibroblasts were approximately two-fold higher as compared to assay conditions without KCN (van Vlies et al. 2007). It should be noted, however, that this finding does not mean that the previously used method was not suitable for diagnosing patients with deficiencies of CPT1. In order to avoid the use of radioactive chemicals, we have modified the assay and turned it into a highly sensitive, non-radioactive tandem-MS-based assay by using $\left[\mathrm{U}-^{13} \mathrm{C}\right]$-palmitoyl-CoA rather than $\left[1-{ }^{14} \mathrm{C}\right]$-palmitoylCoA. The assay was validated by measuring the activity of CPT1 in cell lines of five patients with a full, genetically confirmed deficiency of CPT1, which revealed no detectable CPT1 activity (van Vlies et al. 2007). We have been using this assay for a few years now and have found that it is a very robust and powerful method. Although it is not a standard procedure, the assay can also be applied to cell and tissue homogenates.

\section{$C A C T$}

CACT catalyzes the transport of carnitine and acylcarnitines of various chain lengths by an exchange mechanism (Palmieri 2004). CACT activity can only be measured either in freshly prepared mitochondria, or in selectively permeabilized cells which is the method preferred by ourselves. Murthy et al. (1986) developed an assay for the carnitine/acylcarnitine translocase applicable to biopsied specimens without requiring isolation of mitochondria. This method was adapted by Pande et al. (1993) and modified to allow measurement 
of CACT-activity in permeabilized fibroblasts using digitonin as permeabilizing agent. This assay measures the formation of $\left[{ }^{14} \mathrm{C}\right]$-acetylcarnitine from added $\left[2-{ }^{14} \mathrm{C}\right]$ pyruvate in the mitochondrion and requires the active participation of the pyruvate transporter, pyruvate dehydrogenase, CRAT, and CACT to allow uptake of carnitine (needed in the CRAT reaction) in exchange for radiolabeled acetylcarnitine (Fig. 3a). Furthermore, malonate was added to the incubation medium to prevent degradation of acetyl-CoA in the Krebs cycle by inhibiting succinate dehydrogenase and thereby blocking the generation of oxaloacetate (Fig. 3a).

As an alternative to the use of radiolabeled pyruvate, which may be troublesome at times, we have developed a different method in which the formation of $\left[{ }^{14} \mathrm{C}\right]-\mathrm{CO}_{2}$ from $\left[1-{ }^{14} \mathrm{C}\right]$-acetylcarnitine is measured to determine CACT activity (IJlst et al. 2001). The principle of our method is that the $\left[1-{ }^{14} \mathrm{C}\right]$-acetylcarnitine enters the mitochondrion via CACT followed by the conversion of $\left[1-{ }^{14} \mathrm{C}\right]$-acetylcarnitine into $\left[1-{ }^{14} \mathrm{C}\right]$-acetyl-CoA catalyzed by CRAT after which the radiolabeled acetyl-CoA is oxidized in the Krebs cycle generating $\left[{ }^{14} \mathrm{C}\right]-\mathrm{CO}_{2}$ (Fig. $3 b$ ).

Although the two methods developed by Pande et al. (1993), Murthy et al. (1986) and ourselves (IJlst et al. 2001) work very well in practice, a drawback of the two methods is that both assays are not true single-enzyme (or in this case single-transporter) assays since both methods require the active participation of a number of additional auxiliary enzymes (Fig. 3). There is definitely a need for a single one-step assay.

\section{CPT2}

Since the reaction catalyzed by CPT2, i.e. palmitoylcarnitine $+\mathrm{CoASH} \rightarrow$ palmitoyl-CoA + carnitine, is readily reversible, the activity of CPT2 can be measured either in the forward or backward reaction. The notion that long-chain acylcarnitines can easily be extracted from aqueous solutions by means of butanol has led to the development of a very popular assay in which tissue homogenates, mitochondria, or membrane preparations are incubated in a medium containing radiolabeled carnitine and palmitoyl-CoA plus a detergent like Triton X-100 to inactivate CPT1, followed by extraction of radiolabeled palmitoylcarnitine. Although this method works fine, alternative assays have been developed in which CPT2 is measured in the forward, physiological direction like we do in our laboratory (see Table 2). An important reason for this is that the maximal rate of CPT2 in the forward reaction is markedly higher than in the reverse direction. In fibroblasts from CPT2-deficient patients with either deletions or mutations in the CPT2 gene leading to premature stopcondons, the activity of CPT2 is fully deficient using the assay developed in our laboratory.
A

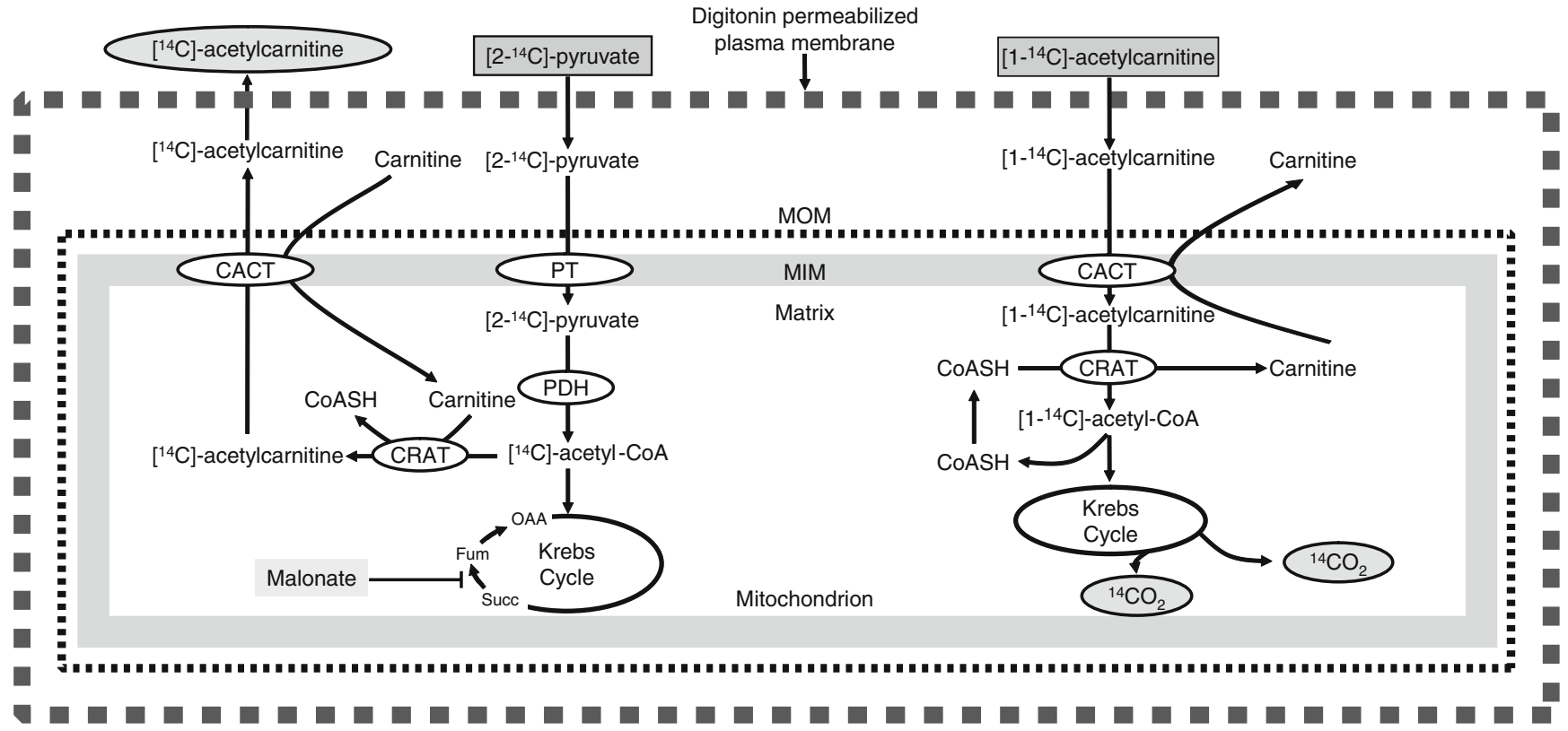

Fig. 3 Principal features of two carnitine acylcarnitine translocase (CACT) activity assays. a The method devised by Pande and coworkers involves the use of $\left[2-{ }^{14} \mathrm{C}\right]$-pyruvate with $\left[{ }^{14} \mathrm{C}\right]$-acetylcarni- tine as end product (Murthy et al. 1986). b The assay developed by IJlst et al. (2001) measures the formation of radiolabeled $\mathrm{CO}_{2}$ from $\left[{ }^{14} \mathrm{C}\right]$-acetylcarnitine 
Several alternative assays have been described in the literature, including the one described by Rettinger et al. (2002). In this elegant and powerful assay, a coupled reaction system is used in which the carnitine produced from palmitoylcarnitine in the CPT2 reaction is directly converted into acetylcarnitine, which is then quantified by tandem mass-spectrometry.

\section{The mitochondrial fatty acyl-CoA oxidation system}

The actual beta-oxidation process involves the concerted action of multiple enzymes present in mitochondria. For the oxidation of straight-chain acyl-CoAs like palmitoyl-CoA, a series of chain-length specific acyl-CoA dehydrogenases (ACADs), enoyl-CoA hydratases (EHs), 3-hydroxyacylCoA dehydrogenases (3HADs), and 3-ketoacyl-CoA thiolases (KATs) are required to catalyze the cyclic release of acetyl-CoA units (Fig. 1).

A

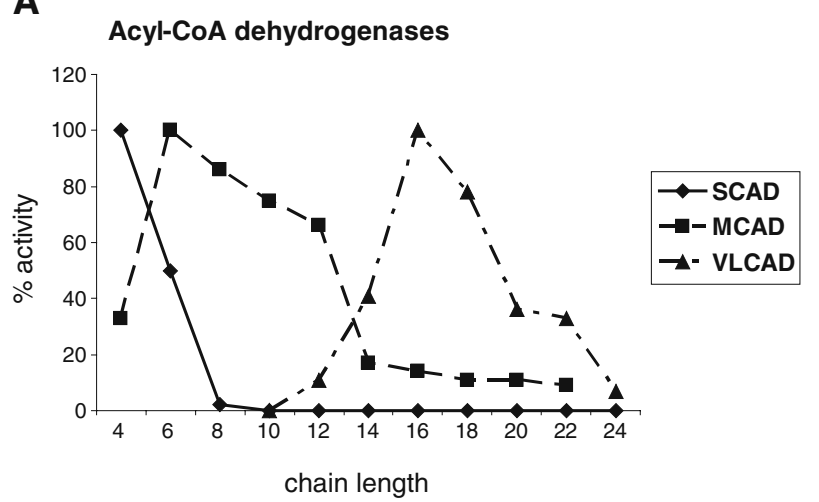

C

3-Hydroxyacyl-CoA dehydrogenases

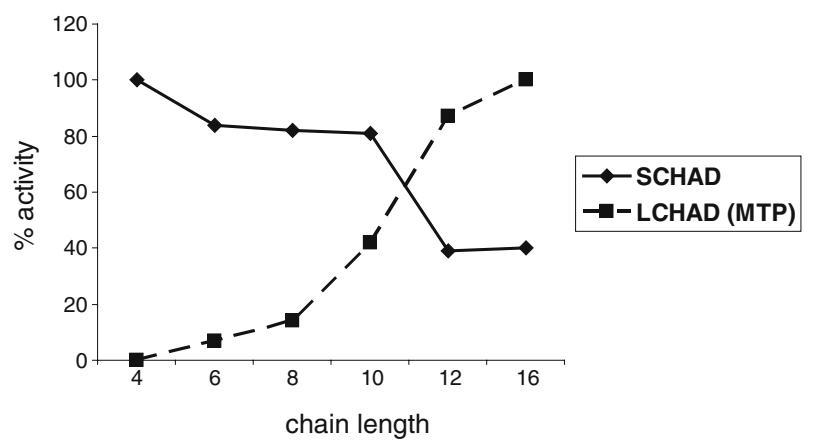

Fig. 4 Substrate specificities of the different mitochondrial betaoxidation enzymes. a Reactivity of the different rat acyl-CoA dehydrogenases with acyl-CoA esters ranging from $\mathrm{C} 4: 0$ to $\mathrm{C} 24: 0-$ CoA (SCAD, MCAD, and VLCAD). Data compiled from Furuta et al. (1981, Izai et al. (1992) and Ensenauer et al. (2005). b Reactivity of crotonase and the long-chain enoyl-CoA hydratase component of MTP as purified from rat liver with $\alpha$, $\beta$-unsaturated acyl-CoAs
Oxidation of branched-chain fatty acids as well as unsaturated fatty acids requires the participation of a range of auxiliary enzymes, including 2-methylacyl-CoA racemase, $\Delta 3, \Delta 2$-enoyl-CoA isomerases, 2,4-dienoylCoA reductases, and $\Delta^{3,5}, \Delta^{2,4}$ dienoyl-CoA reductases, which will not be discussed here (see Hiltunen and Qin 2000 for review).

\section{Acyl-CoA dehydrogenases}

Studies in the 1950s (see Beinert 1990 for review) have led to the identification of three different ACADs each having specific substrate specificities referred to as short-chain (SCAD), medium-chain (MCAD), and long-chain (LCAD) acyl-CoA dehydrogenase (Fig. 4a). All enzymes are homotetramers, localized in the mitochondrial matrix, with a native molecular weight of $160-180 \mathrm{kDa}$ with each subunit carrying a flavin adenine dinucleotide (FAD) bound noncovalently to the enzyme. It was long thought that LCAD
B



D



ranging from $\mathrm{C} 4$ to $\mathrm{C} 16$. c Reactivity of $S C H A D$ and the $L C H A D$ component of MTP as purified from rat liver with 3-ketoacyl-CoAs ranging from $\mathrm{C} 4$ to $\mathrm{C} 16$. d Reactivity of medium-chain 3-ketoacylCoA thiolase and the long-chain 3-ketoacyl-CoA thiolase component of MTP as isolated from rat liver with 3-ketoacyl-CoAs ranging from C4 to C16. Data taken from Izai et al (1992) 
would be responsible for the first cycles of beta-oxidation of long straight-chain acyl-CoAs. This was later disproven (Yamaguchi et al. 1993) and resolved by Bertrand et al. (1993) and Aoyama et al. (1993) following the discovery of a new acyl-CoA dehydrogenase, named VLCAD, by Hashimoto and co-workers (Izai et al. 1992). VLCAD is a dimer of two identical subunits bound to the inner mitochondrial membrane (Fig. 1) and accepts long chain acyl-CoAs as substrate (Fig. 4a).

The different ACADs catalyze the following reaction:

acyl-CoA $+\mathrm{FAD} \rightarrow$ trans-2-enoyl-CoA $+\mathrm{FADH}_{2}$

It is now clear that oxidation of long straight-chain acyl-CoAs involves the subsequent action of VLCAD, MCAD, and SCAD, respectively, with virtually no contribution of LCAD in humans. In rodents, however, LCAD does play a significant role in FAO (Chegary et al. 2009). In addition to the four ACADs described above, a number of additional ACADs have been identified of which ACAD9 has been claimed to play a prominent role in the oxidation of long-chain FAs in human brain. Indeed, studies by Vockley and co-workers (Ensenauer et al. 2005) have shown that ACAD9 is highly expressed in human brain, and is mostly localized to subpopulations of neurons in which LCHAD/MTP is also expressed, most notably in the cerebellum (He et al. 2007). The finding that the substrate specificity of ACAD9 mimics that of VLCAD, in combination with the observation that ACAD9 is, in fact, expressed in the CNS in humans and the chronic neurological abnormalities in the ACAD9-deficient patients reported by $\mathrm{He}$ et al. (2007), provide support for a previously unappreciated but important role of ACAD9 in the mitochondrial betaoxidation of long-chain fatty acids in neuronal tissue. In fibroblasts, ACAD9 is well expressed but does not contribute to long-chain acyl-CoA dehydrogenase activity using palmitoyl-CoA as substrate as discussed later in this review.

\section{Enoyl-CoA hydratases}

EHs catalyze the following reaction:

trans-2-enoyl-CoA $+\mathrm{H}_{2} \mathrm{O} \leftrightarrow$ L-3-hydroxyacyl-CoA.

Mitochondria contain different EHs of which the short-chain enoyl-CoA hydratase (alternative name: crotonase), and longchain enoyl-CoA hydratase, as part of the mitochondrial trifunctional protein (MTP) are involved in the oxidation of long straight-chain acyl-CoAs. Crotonase acts on 2-enoyl-
CoAs ranging from crotonyl-CoA $(\mathrm{C} 4: 1-\mathrm{CoA})$ to 2-transhexadecenoyl-CoA (C16:1-CoA) with decreasing efficiency. The latter substrate is only hydrated at a rate of $1-2 \%$ of that of crotonyl-CoA (Fig. 4b). Crotonase catalyzes the cisaddition of $\mathrm{H}_{2} \mathrm{O}$ and also accepts 2-cis-enoyl-CoAs as substrates, converting them into D-3-hydroxyacyl-CoAs. The long-chain enoyl-CoA hydratase as part of MTP shows highest activity with the C16:1 substrate whereas activity with the C6:1 substrate and especially C4:1 (crotonyl-CoA) substrate is virtually zero, suggesting that crotonase is required, at least for the hydratation of crotonyl-CoA (Fig. 4b). The fact that crotonase shows high activity with the $\mathrm{C} 4: 1$ substrate but not the $\mathrm{C} 16: 1$ substrate, whereas the reverse is true for the long-chain enzyme, allows easy discrimination between the two enzymes in tissue preparations, fibroblasts and other cells.

\section{3-Hydroxyacyl-CoA dehydrogenases}

3HADs catalyze the following reaction:

$$
\begin{array}{r}
\text { L-3-hydroxyacyl-CoA }+\mathrm{NAD}^{+} \\
\rightarrow \text { 3-ketoacyl-CoA }+\mathrm{NADH.}
\end{array}
$$

Mitochondria contain different 3HADs, including a short-chain 3-hydroxyacyl-CoA dehydrogenase (SCHAD) and long-chain 3-hydroxyacyl-CoA dehydrogenase (LCHAD) as part of MTP. Both enzymes are required for the proper oxidation of long straight-chain acyl-CoAs. SCHAD shows broad activity with 3hydroxyacyl-CoAs ranging from $\mathrm{C} 4$ to $\mathrm{C} 16$, whereas the LCHAD component of MTP shows highest activity with the $\mathrm{C} 16$ substrate with virtually no reactivity with the C4 substrate (Fig. 4c), suggesting that SCHAD is indispensible at least for the oxidation of the $\mathrm{C} 4$ substrate. This is in line with the findings in SCHAD- versus LCHAD-deficient patients as discussed later.

\section{3-Ketothiolases}

KATs catalyze the following reaction:

$$
\begin{aligned}
& \text { 3-ketoacyl-CoA }+\mathrm{CoASH} \\
& \rightarrow(\mathrm{n}-2) \text { acyl-CoA }+ \text { acetyl-CoA. }
\end{aligned}
$$

Mitochondria contain at least three KATs. For the proper oxidation of long straight-chain acyl-CoAs, the long-chain thiolase (LCKAT) as part of MTP is essential, as demonstrated by the findings in patients with isolated LCKAT deficiency (Das et al. 2006) as well as in patients with a full deficiency of MTP (Wanders et al. 1992). The long-chain thiolase of MTP is reactive with a range of 3-ketoacyl- 
CoAs ranging from $\mathrm{C} 16$ tot $\mathrm{C} 6$ with no activity with the $\mathrm{C} 4$ substrate (Fig. 4d).

The second mitochondrial thiolase was initially called "general thiolase", but has later been renamed into mediumchain 3-ketothiolase (MCKAT) by Kamijo et al. (1997). The function of this thiolase in fatty acid beta-oxidation remains to be established despite the fact that Kamijo et al (1997) described a patient with a presumed defect at the level of MCKAT. In the absence of any definitive proof which includes molecular analysis of the underlying gene, it remains to be established whether MCKAT is truly deficient in this patient.

Mitochondria also contain a third thiolase often referred to as "beta-ketothiolase" with 2-methylacetoacetyl-CoA as unique substrate. This thiolase does not play any role in FAO but is indispensable for isoleucine degradation (Mitchell and Fukao 2001).

All the enzymes described above have been purified, characterized and cloned. The mitochondrial trifunctional protein has been purified from different sources (Uchida et al. 1992; Carpenter et al. 1992; Luo et al. 1993) and is a hetero-octamer of 4 alpha-and 4 beta-subunits with the alpha-subunit $(79 \mathrm{kDa})$ carrying the enoyl-CoA hydratase activity and 3-hydroxyacyl-CoA dehydrogenase activity, whereas the beta-subunit harbours the thiolase component (Uchida et al. 1992).

\section{Enzymatic analysis of the mitochondrial acyl-CoA beta-oxidation system}

\section{Acyl-CoA dehydrogenases}

The specific measurement of each of the individual ACADs in a mitochondrial preparation, or preferably in total cell homogenates, requires at least two things: (1) a specific substrate preferably reactive with only one particular ACAD; and (2) a specific detection system allowing the activity of each ACAD to be measured. The first condition is only met for MCAD if 3-phenylpropionyl-CoA is used as substrate since 3-phenylpropionyl-CoA is a unique substrate for MCAD (Lehman et al. 1990). Although palmitoyl-CoA is a substrate for multiple ACADs (see Fig. 4a), we and others have found that palmitoyl-CoA is a specific substrate for VLCAD in homogenates of cultured skin fibroblasts and lymphocytes. This is concluded, among others, from the observation that the acyl-CoA dehydrogenase activity measured with palmitoyl-CoA as substrate is fully deficient in fibroblasts (Fig. 5a) and in lymphocytes (Fig. 5b) from patients with genetically confirmed VLCAD-deficiency (Fig. 5a). This indicates that ACAD9 does not contribute to the palmitoyl-CoA dehydrogenase activities in these cell types despite its significant expression levels. For SCAD, a specific substrate which is not handled by any of the other ACADs has not yet been identified. Butyryl-CoA is usually used as substrate. Since butyryl-CoA is also a substrate for other ACADs (Fig. 4a), corrections have to be made for the contribution by the other ACADs. One method which we favor in our laboratory is to measure the butyryl-CoA dehydrogenase activity in homogenates before and after immunoprecipitation of SCAD using a specific antibody (Wanders et al., in preparation).

In the early years, acyl-CoA dehydrogenase activities were measured fluorimetrically and/or spectrophotometrically using different dye-reduction assays, which are based on the use of artificial electron acceptors such as dichlorophenol-indophenol (DCPIP) with either phenazine methosulphate (PMS) or ETF (Rhead et al. 1983) as mediator. These types of assays have a number of drawbacks, including the relatively high background plus the
A

Fibroblasts

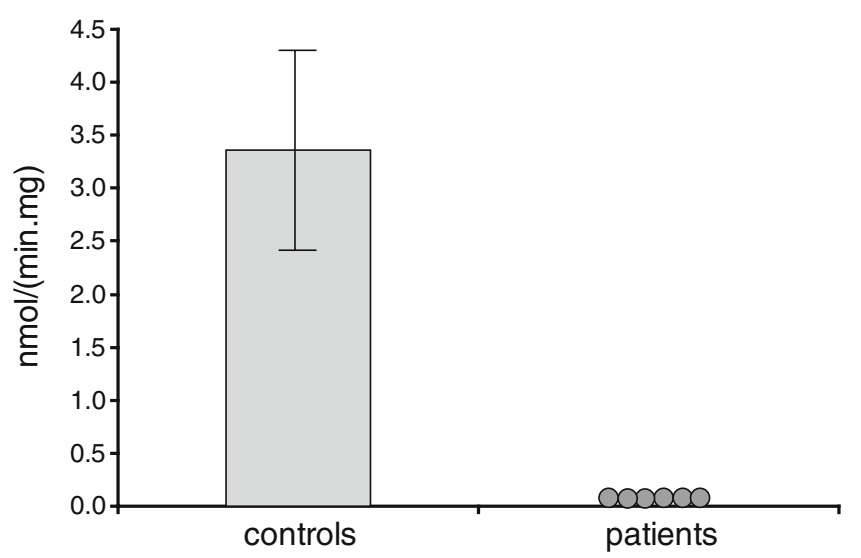

B

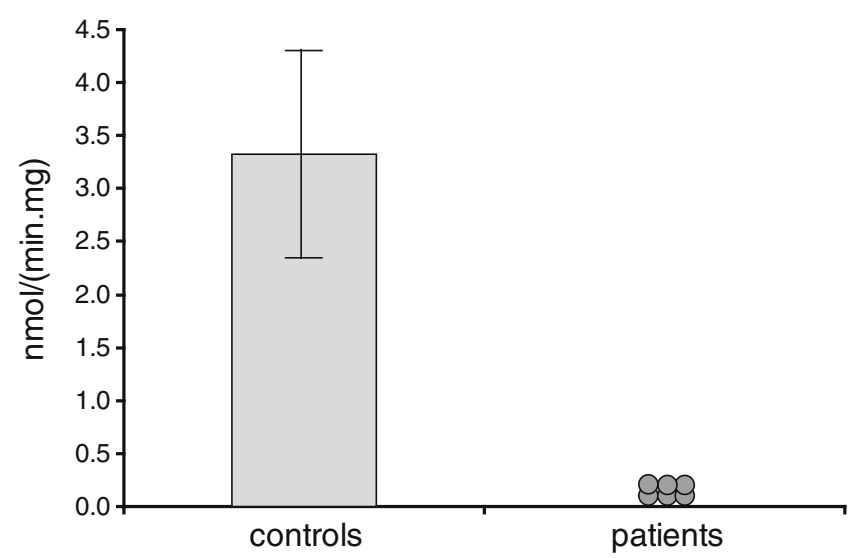

Fig. 5 Results of VLCAD activity measurements in fibroblasts (a) and lymphocytes (b) from controls and genetically proven VLCADD-patients 
fact that only isolated mitochondria or even more purified fractions can be used in the assay. Although different improved variations on this theme have been devised (Dommes and Kunau 1976), there was a clear need for new assays. One was the ETF-based assay, which has remained the method of choice for many years for measurement of SCAD, MCAD, and VLCAD in patients' cells (Stanley et al. 1983; Coates et al. 1985). Oxidized ETF is highly fluorescent, and this fluorescence is lost upon the reduction of ETF by any of the acyl-CoA dehydrogenases, thus yielding a sensitive and accurate technique. Unfortunately, ETF has never become commercially available and, in addition, the assay needs to be done anaerobically, which in practice yields problems. For this reason alternative assays have been devised including the tritium-release assay for MCAD using $\left[2,3-{ }^{3} \mathrm{H}\right]$-octanoyl-CoA as substrate (Amendt and Rhead 1985).

Kolvraa et al. (1982) were the first to device a completely different method based on the identification of the products of the ACAD reaction, in their case MCAD, using gas chromatography-mass spectrometery. Different variations on this theme have been published by several authors (Niezen-Koning et al. 1992, 1994; Duran et al. 1992).

In 1990, Lehman and Thorpe (1990) published a direct spectrophotometric method for MCAD based on the use of ferricenium hexafluorophosphate. The method involves measurement of the 3-phenylpropionyl-CoA mediated reduction of the ferricenium ion at $303 \mathrm{~nm}$. We have adopted the same principle to measure the activity of VLCAD (IJlst et al. 1994). However, it soon turned out that these spectrophotometric methods for MCAD and VLCAD, respectively, lack robustness and sensitivity, and, more importantly, lead to artificially high residual activities, amounting to $50 \%$ of normal in fibroblasts from patients with a full deficiency of MCAD (Taylor et al. 1992). Similar high residual activities were found for VLCAD in fibroblasts using the ferricenium-based assay in fibroblasts from patients with a full deficiency of VLCAD (IJlst and Wanders 1993a).

Since ferricenium hexafluorophosphate was (and is) commercially available, we (Wanders et al. 1999; Oey et al. 2006) devised a new type of assay for measurement of ACAD activities, which involves the use of ferricenium hexafluorophosphate as electron acceptor followed by the analysis of the products of the ACAD reaction by HPLC coupled to UV-detection or by UPLC coupled to tandemMS detection (Table 2). This method is now also used by others (Spiekerkoetter et al. 2003; Tajima et al. 2005, 2008; ter Veld et al. 2009). We have been using this assay for VLCAD, MCAD, and SCAD analysis (see Table 3). Moreover, we are using the same methodology for the analysis of other ACADs, which include glutaryl-CoA dehydrogenase, isovaleryl-CoA dehydrogenase, short branched-chain acyl-CoA dehydrogenase, and ACAD8.

Figure 6 shows typical HPLC/UV chromatograms of our MCAD assay for fibroblasts (Fig. 6a) and lymphocytes (Fig. 6b) from control subjects and MCAD-deficient
A
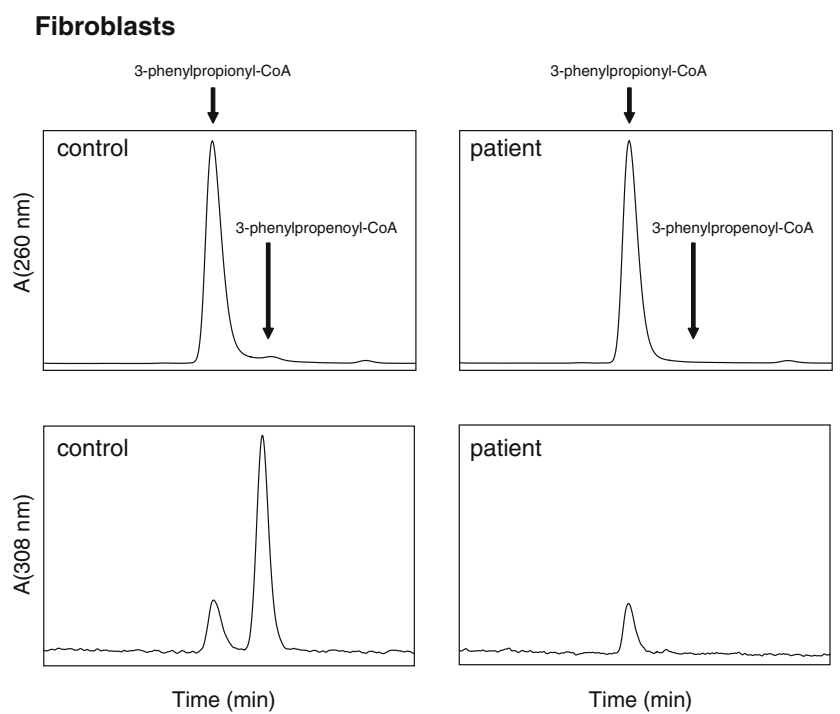

Fig. $6 \mathrm{HPLC} / \mathrm{UV}$-chromatograms of extracts, prepared from incubations in which fibroblasts (a) or lymphocytes (b) from control and genetically proven MCADD-patients were incubated with 3-
B
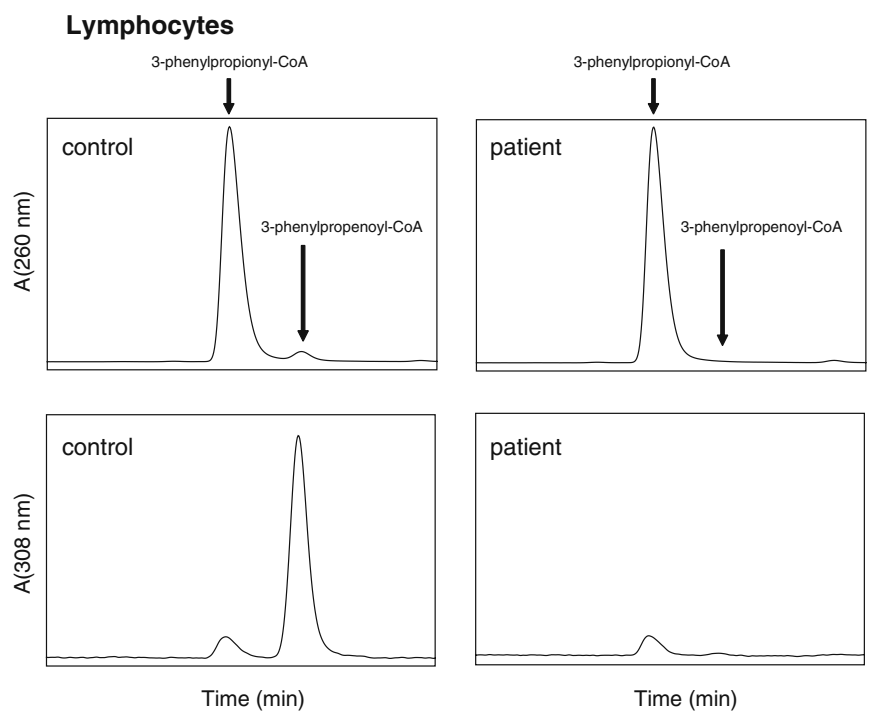

phenylpropionyl-CoA in the presence of ferricenium hexafluorophosphate. Recordings were done at $303 \mathrm{~nm}$ and $260 \mathrm{~nm}$, respectively 
patients homozygous for the c. $985 \mathrm{~A}>\mathrm{G}$ mutation. The finding of a virtually full deficiency of MCAD in both fibroblasts and lymphocytes of patients homozygous for the $985 \mathrm{~A}>\mathrm{G}$ mutation (Fig. 6) allows easy discrimination between controls and patients and inspired us to propose direct analysis of MCAD in lymphocytes in neonates with a positive neonatal screening result for MCAD, as a first-line test next to acylcarnitine analysis in a new blood sample. Figure 7 shows our results obtained in 2007 and 2008, the first two years of the Dutch extended neonatal screening program. The results for the 16 neonates with a positive screening result for MCADD in 2007 show that 11 of the 16 neonates analyzed by us were clearly MCAD-deficient. In the remaining 5 neonates, MCAD activities were not deficient, with activities ranging between 40 and $180 \%$ (Fig. 7a). In 2008, 10 of the 15 neonates suspected to have MCADD were clearly MCAD-deficient, whereas a fully normal activity was found in neonate 15 . Four out of the 15 neonates had intermediate values for MCAD in lymphocytes ranging from $21 \%$ in neonate 11 to $39 \%$ in neonate 14 (Fig. 7b). Neonates 13 and 14 turned out to be true heterozygotes for MCADD. Detailed follow-up studies in fibroblasts from neonates 11 and 12, however, revealed that both had true MCAD-deficiency, albeit mild. This was concluded from the results of the palmitate loading test in which cells are loaded with palmitate followed by acylcarnitine profiling (Ventura et al. 1999), which revealed an abnormal profile with a mildly elevated octanoylcarnitine level. Furthermore, measurement of MCAD-activity in fibroblasts from neonates 11 and 12 revealed clear deficiencies. Molecular analysis revealed mutations in both

\section{A}

2007

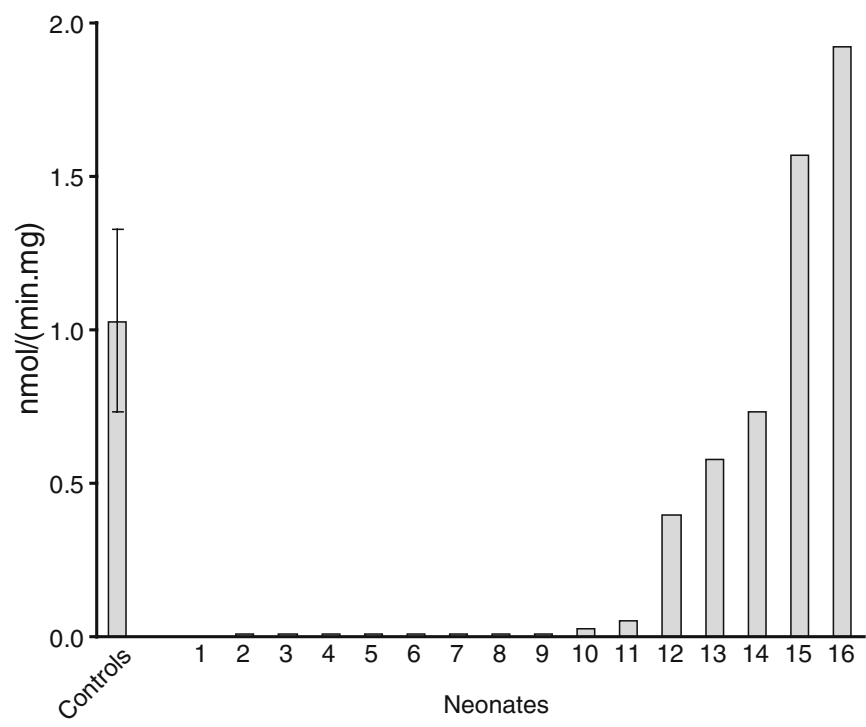

MCAD alleles in these patients. A full account of these data will be published separately.

The same strategy is used for the follow-up of neonates with a positive VLCAD screening result. Figure 8 shows the results obtained in 2007 and 2008 with respect to neonates with an abnormal acylcarnitine profile pointing to VLCAD deficiency as detected upon neonatal screening. In 2007 , only one neonate was identified in the Netherlands with a positive screening result suggestive for VLCADD. We received blood from this neonate, isolated lymphocytes, and found a partial deficiency pointing to mild VLCADdeficiency (Fig. 8). In 2008, three neonates were picked up by neonatal screening with an acylcarnitine profile suggestive for VLCAD. In two of these neonates, VLCAD was measured in lymphocytes with clear deficiencies in both of them (Fig. 8).

\section{Short-chain 3-hydroxyacyl-CoA dehydrogenase}

The activity of the different 3HADs is usually measured in the reverse direction because the equilibrium of the 3HADreaction drives the reaction backwards, unless the product of the 3HAD-reaction is constantly metabolized via the direct and continuous thiolytic cleavage of the 3-ketoacylCoA ester, the product of the 3HAD-reaction. 3HAD activities can simply be measured by following the 3ketoacyl-CoA ester-dependent consumption of NADH at $340 \mathrm{~nm}$. Fortunately, the activity of SCHAD can be measured directly in skin fibroblast and lymphocyte homogenates using acetoacetyl-CoA as substrate. Acetoacetyl-CoA is unique for SCHAD, because the

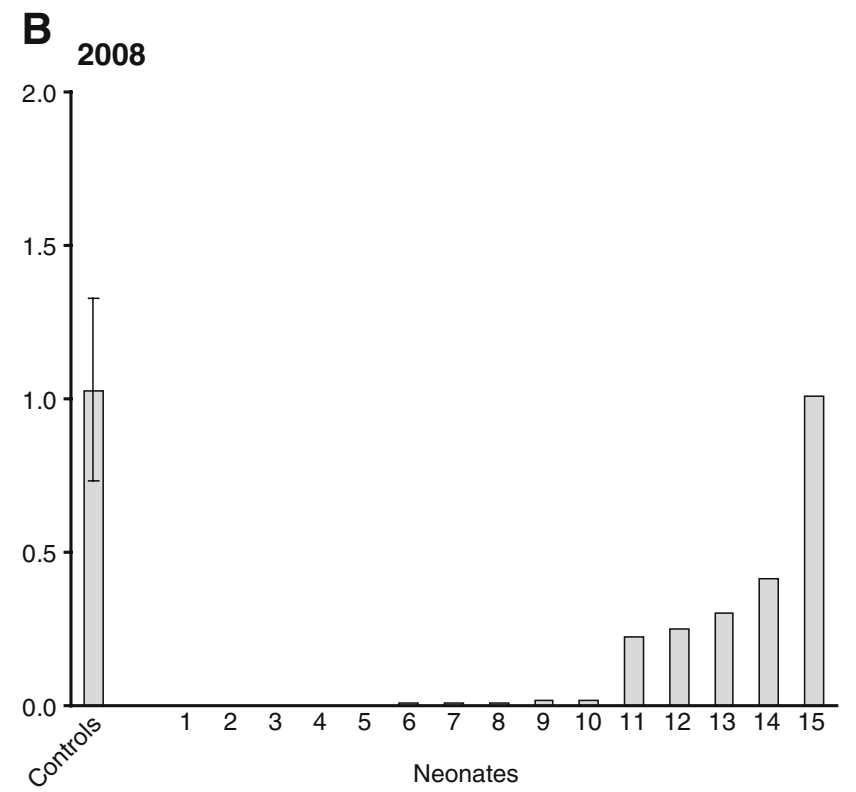

Fig. 7 Cumulative results of the MCAD-activity measurements in lymphocytes from neonates with a positive screening result for MCADD as sent to us in 2007 (a) and 2008 (b) 


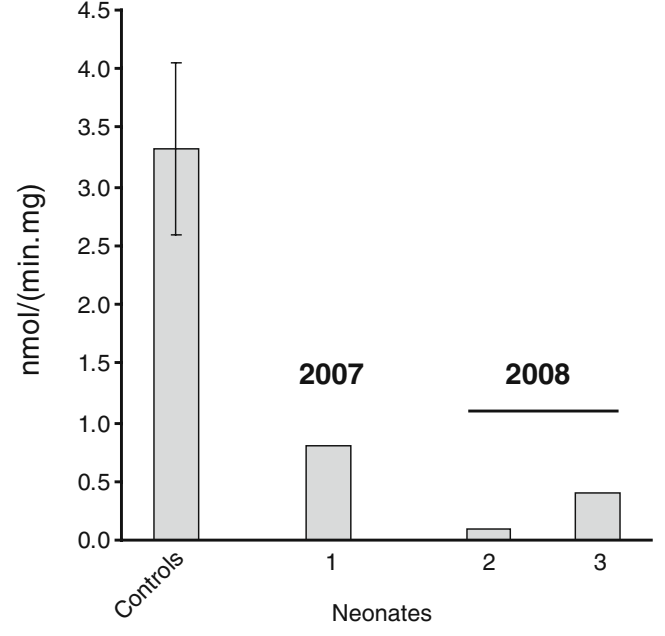

Fig. 8 Results of the VLCAD-activity measurements in lymphocytes from neonates with a positive screening result for VLCADD, as sent to us in 2007 and 2008

LCHAD component of MTP is fully unreactive towards this substrate (Fig. 4c). Indeed, in fibroblasts of genetically proven SCHAD-deficient patients, the 3HAD-activity as measured with acetoacetyl-CoA was almost fully deficient, as shown in Fig. 9a for the two established SCHADdeficient patients (siblings) identified by Molven et al. (2004) with intermediate activities in fibroblasts from the parents. A similar marked deficiency of SCHAD was found in lymphocytes from the only patient with proven SCHADdeficiency we have analyzed so far (Fig. 9b).

\section{Long-chain 3-hydroxyacyl-CoA dehydrogenase}

Unfortunately, a specific substrate only reacting with the LCHAD-component of MTP has not yet been identified. In our hands, 3-ketopalmitoyl-CoA is the best substrate for LCHAD at present. In fibroblasts, about $75 \%$ of the activity as measured with 3-ketopalmitoyl-CoA is catalyzed by LCHAD, whereas the remaining $25 \%$ is derived from SCHAD. We have searched for methods allowing the assay to be more specific. One method involves the selective immunoprecipitation of SCHAD from homogenates prior to enzymatic analysis using antibodies raised against SCHAD. Although the method works fine in practice, we prefer the second method we devised which is based on the finding that N-ethylmaleimide, a SH-reagent, is a powerful inhibitor of LCHAD with no effect on SCHAD (IJlst and Wanders 1993b). In practice, this means that we measure the 3-ketopalmitoyl-CoA dehydrogenase activity in the absence and presence of N-ethylmaleimide. The difference between the two rates then represents true LCHAD-activity. Figure $10 \mathrm{a}, \mathrm{b}$ shows the results of such LCHAD-activity measurements in fibroblasts (Fig. 10a) and lymphocytes (Fig. 10b) from 8 and 5 genetically proven LCHADDpatients, respectively.

\section{3-Ketoacyl-CoA thiolases}

The most popular assay for measurement of KAT activities is that in which the consumption of the 3-ketoacyl-CoA ester is measured spectrophotometrically at $303 \mathrm{~nm}$. The method is based on the notion that 3-ketoacyl-CoAs absorb at $303 \mathrm{~nm}$, when magnesium ions are present. As discussed before, mitochondria contain at least three different thiolases of which the short-chain thiolase with 2methylacetoacetyl-CoA as specific substrate is inactive in the absence of potassium ions. Furthermore, MCKAT is fully inactive with 3-ketopalmitoyl-CoA (see Fig. 4d) so that the thiolase activity of MTP can be measured specifically by using 3-ketopalmitoyl-CoA as substrate in a medium lacking potassium ions.

\section{ETF-alpha, ETF-beta and ETF-dehydrogenase}

Although ETF-alpha, ETF-beta, and ETF-dehydrogenase are strictly speaking not directly involved in fatty acid betaoxidation, they do play an essential role by transferring the electrons coming from the acyl-CoA dehydrogenases to the respiratory chain at the level of coenzyme Q. Measurement of
Fig. 9 Results of the acetoacetyl-CoA dehydrogenase (SCHAD) activity measurements in fibroblasts (a) and lymphocytes (b)
A

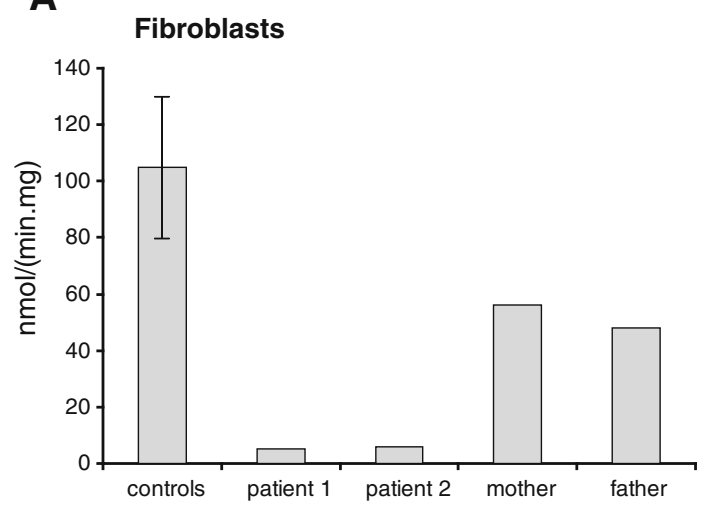

B

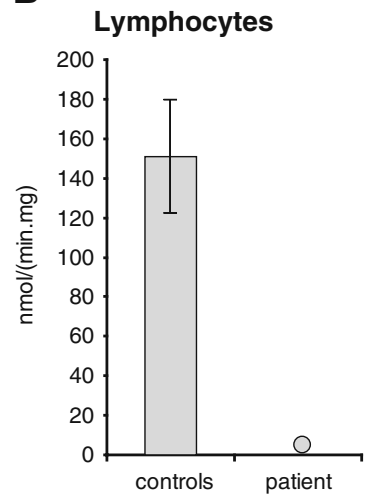



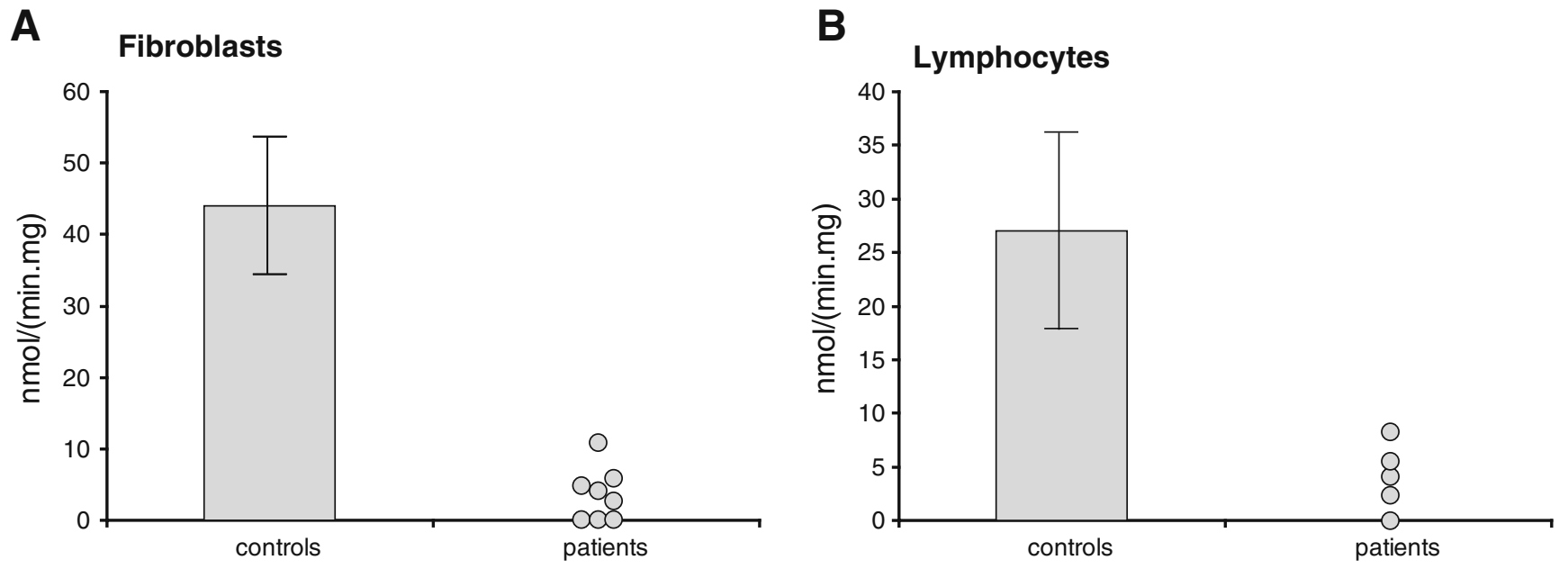

Fig. 10 Results of the LCHAD-activity measurements in fibroblasts (a) and lymphocytes (b) from control subjects and established, genetically proven LCHADD-patients

ETF-alpha, ETF-beta, and ETF-dehydrogenase has notoriously been difficult. In order to measure ETF-dehydrogenase, for instance, purified ETF is required. In our laboratory, we favor direct sequence analysis of the ETFA, ETFB, and ETFDH genes in any patients suspected to suffer from glutaric aciduria type 2 based on urinary organic acid analysis and/or acylcarnitine analysis. Sequence analysis of these genes is available in our laboratory. It should be noted that direct enzymatic analysis of ETF and ETF-DH is operational in other laboratories including the Lyon-lab, headed by Christine Vianey-Saban (personal communication).

\section{Whole cell fatty acid oxidation studies}

Since acylcarnitine profiling in plasma from patients may be so stunningly predictive in terms of which enzyme or transporter is deficient (Fig. 2), whole cell fatty acid oxidation studies have lost its importance as a first line

Table 3 List of enzymatic and molecular tests as available for the mitochondrial beta-oxidation deficiencies

\begin{tabular}{|c|c|c|c|c|}
\hline \multirow[t]{3}{*}{ Enzyme } & \multicolumn{3}{|c|}{ Enzymatic testing } & \multirow[t]{3}{*}{ Molecular testing } \\
\hline & \multicolumn{2}{|c|}{ Lymphocytes } & \multirow[t]{2}{*}{ Fibroblasts } & \\
\hline & Fresh & Frozen & & \\
\hline 1. Plasma membrane carnitine transporter (OCTN2) & + & - & + & + \\
\hline 2. Carnitine palmitoyltransferase 1 (CPT1) & + & - & + & + \\
\hline 3. Mitochondrial carnitine/acylcarnitine translocase (CACT) & + & - & + & + \\
\hline 4. Carnitine palmitoyltransferase 2 (CPT2) & + & + & + & + \\
\hline 5. Very-long-chain acyl-CoA dehydrogenase (VLCAD) & + & + & + & + \\
\hline 6. Medium-chain acyl-CoA dehydrogenase (MCAD) & + & + & + & + \\
\hline 7. Short-chain acyl-CoA dehydrogenase (SCAD) & + & + & + & + \\
\hline 8. Isolated long-chain 3-hydroxyacyl-CoA dehydrogenase (LCHAD) & + & + & + & + \\
\hline 9. Isolated long-chain 3-ketothiolase (LCKAT) & + & + & + & + \\
\hline 10. Short-chain 3-hydroxyacyl-CoA dehydrogenase (SCHAD) & + & + & + & + \\
\hline 11. Medium-chain 3-ketoacyl-CoA thiolase (MCKAT) & - & - & + & - \\
\hline 12. ETF dehydrogenase (ETFDH) & $-*$ & $-*$ & $-*$ & + \\
\hline 13. ETF-alpha $(\mathrm{ETF} \alpha)$ & $-^{*}$ & $-*$ & -* & + \\
\hline 14. ETF-beta $(\mathrm{ETF} \beta)$ & $-^{*}$ & $-^{*}$ & -* & + \\
\hline
\end{tabular}

+ Test available in our laboratory; - test not available in our laboratory; for more details see: www.labgmd.nl, -* test available in other laboratories (see text) 
test. Rather, fatty acid oxidation studies are only done if direct enzymatic analysis has not led to the identification of the enzyme defect. Furthermore, whole cell fatty acid oxidation studies are warranted to determine the effect of a certain deficiency of an enzyme on flux through the mitochondrial beta-oxidation system. This is especially relevant in case of partial enzyme deficiencies as found in patients picked up by neonatal screening programs as described above from MCADD (Fig. 7).

Through the years, many different methods have been set up for this purpose, including: (1) $\left[{ }^{14} \mathrm{C}\right]-\mathrm{CO}_{2}$ release assays using different $\left[1-{ }^{14} \mathrm{C}\right]$ - or $\left[\mathrm{U}-{ }^{14} \mathrm{C}\right]$-labelled fatty acids; (2) tritium release assays using different $\left[{ }^{3} \mathrm{H}\right]$-labelled fatty acids, notably $\left[9,10-{ }^{3} \mathrm{H}\right]$-myristic acid, $\left[9,10-{ }^{3} \mathrm{H}\right]$ palmitic acid, and $\left[9,10-{ }^{3} \mathrm{H}\right]$-oleic acid (Manning et al. 1990; Olpin et al. 1992, 1997); and (3) quantitative acyl$\mathrm{CoA}$ and acylcarnitine profiling studies. The latter methods have been pioneered by Bartlett and co-workers in the late 1980s during studies on the beta-oxidation of fatty acids in rat liver mitochondria. The methodology involved incubation of mitochondria with radiolabeled fatty acids followed by extraction of the acyl-CoA esters followed by separation on radio-HPLC with continuous on-line monitoring of radioactively labeled acyl-CoAs (Watmough et al. 1988, 1989).

These methods were later improved and extended to include the analysis of both acyl-CoA esters and acylcarnitines, and were subsequently used to study mitochondrial fatty acid oxidation in fibroblasts from patients first using mitochondria isolated from fibroblasts (Kler et al. 1991) and later using selectively permeabilized fibroblasts (Pourfarzam et al. 1994) and peripheral blood cells (Schaefer et al. 1995).

In 1995, Roe and co-workers (Nada et al. 1995) published an elegant method named the acylcarnitine profiling method which involves incubation of intact fibroblasts or lymphoblastoid cells with a deuterated longchain fatty acid $\left(\left[17,17,18,18-{ }^{2} \mathrm{H}_{4}\right]\right.$-linoleic acid) followed by analysis of the acylcarnitines using tandem-mass spectrometry. The profiles are often very characteristic which immediately guides the way to the underlying defect. Several variations on this theme have been published by different groups the main difference being the use of differentially labelled fatty acids including $\left[16-{ }^{2} \mathrm{H}_{3}\right]$-palmitic acid (Vianey-Saban et al. 1998), [U- $\left.{ }^{13} \mathrm{C}\right]$-palmitic acid (Ventura et al. 1999), and $\left[15,15,16,16,16-{ }^{2} \mathrm{H}_{5}\right]$-palmitic acid (Sim et al. 2002; Law et al. 2007).

We have been using the acylcarnitine profiling method with $\left[\mathrm{U}-{ }^{13} \mathrm{C}\right]$ palmitic acid as substrate (Ventura et al. 1999) and the tritium-release assays using tritiated oleic acid for many years now. The reason for subjecting each patient cell line to both these assays is that the tritium-release assay measures the actual rate of fatty acid oxidation with no information on the site of the enzyme block whereas the reverse is true for the acylcarnitine profiling methods, which do provide information on the site of the enzymatic block. Recently, Law et al. (2007) devised an elegant method which couples acylcarnitine profiling via ESI/MS/ MS with the simultaneous measurement of the flux through the beta-oxidation pathway, using $\left[{ }^{2} \mathrm{H}_{31}\right]$-palmitic acid. The rate of fatty acid oxidation was measured from the deuterated water enrichment by means of isotope ratio MS.

It should be emphasized that there is still room for improvement of the currently available whole cell assays since patients with a mild defect in mitochondrial fatty acid oxidation may show no abnormalities in either of the two tests (results not shown). We have experienced this through the years especially in patients with mild deficiencies at the level of VLCAD and LCHAD/MTP, as well as in mild glutaric aciduria type 2 patients. We are continuing our efforts to improve these methods.

\section{Conclusions}

Much has been learned in recent years about the enzymatic and molecular basis of the different mitochondrial beta-oxidation deficiencies. The fact that many, if not all, enzymes of mitochondrial fatty acid oxidation are also expressed in peripheral blood cells allows the rapid identification of the enzymatic defect in patients, suspected to suffer from a FAO disorder on the basis of an abnormal acylcarnitine profile upon neonatal screening or otherwise. Miniaturization of existing enzyme assays may even allow identification of patients using blood spots. Efforts to realize this option are underway. Table 3 provides information on the full series of enzymatic and molecular tests currently available in our laboratory (see also www.labgmd.nl).

Acknowledgements The authors gratefully acknowledge Mrs. Maddy Festen for expert preparation of the manuscript. This work was supported by the Netherlands Organization for Scientific Research (VIDI-grant NWO 016.086.336) to SMH.

Open Access This article is distributed under the terms of the Creative Commons Attribution Noncommercial License which permits any noncommercial use, distribution, and reproduction in any medium, provided the original author(s) and source are credited.

\section{References}

Amendt BA, Rhead WJ (1985) Catalytic defect of medium-chain acylcoenzyme A dehydrogenase deficiency. Lack of both cofactor responsiveness and biochemical heterogeneity in eight patients. J Clin Invest 76:963-969

Aoyama T, Uchida Y, Kelley RI et al (1993) A novel disease with deficiency of mitochondrial very-long-chain acyl-CoA dehydrogenase. Biochem Biophys Res Commun 191:1369-1372 
Beinert H (1990) Fatty acid oxidation in soluble systems of mammalian origin: the beginnings. Prog Clin Biol Res 321:1-22

Bertrand C, Largilliere C, Zabot MT, Mathieu M, Vianey-Saban C (1993) Very long chain acyl-CoA dehydrogenase deficiency: identification of a new inborn error of mitochondrial fatty acid oxidation in fibroblasts. Biochim Biophys Acta 1180:327-329

Carpenter K, Pollitt RJ, Middleton B (1992) Human liver long-chain 3-hydroxyacyl-coenzyme A dehydrogenase is a multifunctional membrane-bound beta-oxidation enzyme of mitochondria. Biochem Biophys Res Commun 183:443-448

Chegary M, te Brinke HT, Ruiter JPN et al (2009) Mitochondrial long chain fatty acid beta-oxidation in man and mouse. Biochim Biophys Acta 1791:806-815

Coates PM, Hale DE, Stanley CA, Corkey BE, Cortner JA (1985) Genetic deficiency of medium-chain acyl coenzyme A dehydrogenase: studies in cultured skin fibroblasts and peripheral mononuclear leukocytes. Pediatr Res 19:671-676

Das AM, Illsinger S, Lucke T et al (2006) Isolated mitochondrial longchain ketoacyl-CoA thiolase deficiency resulting from mutations in the HADHB gene. Clin Chem 52:530-534

Demaugre F, Bonnefont JP, Mitchell G et al (1988) Hepatic and muscular presentations of carnitine palmitoyl transferase deficiency: two distinct entities. Pediatr Res 24:308-311

Dommes V, Kunau WH (1976) A convenient assay for acyl-CoAdehydrogenases. Anal Biochem 71:571-578

Duran M, Cleutjens CB, Ketting D et al (1992) Diagnosis of mediumchain acyl-CoA dehydrogenase deficiency in lymphocytes and liver by a gas chromatographic method: the effect of oral riboflavin supplementation. Pediatr Res 31:39-42

Ensenauer R, He M, Willard JM et al (2005) Human acyl-CoA dehydrogenase- 9 plays a novel role in the mitochondrial betaoxidation of unsaturated fatty acids. J Biol Chem 280:32309-32316

Furuta S, Miyazawa S, Hashimoto T (1981) Purification and properties of rat liver acyl-CoA dehydrogenases and electron transfer flavoprotein. J Biochem (Tokyo) 90:1739-1750

He M, Rutledge SL, Kelly DR et al (2007) A new genetic disorder in mitochondrial fatty acid beta-oxidation: ACAD9 deficiency. Am J Hum Genet 81:87-103

Hiltunen JK, Qin Y (2000) Beta-oxidation-strategies for the metabolism of a wide variety of acyl-CoA esters. Biochim Biophys Acta 1484:117-128

IJlst L, Wanders RJA (1993a) A simple spectrophotometric assay for long-chain acyl-CoA dehydrogenase activity measurements in human skin fibroblasts. Ann Clin Biochem 30:293-297

IJlst L, Wanders RJA (1993b) A simple, straightforward assay for long-chain 3-hydroxyacyl-CoA dehydrogenase based on the use of N-ethylmaleimide: potential for pre- and postnatal diagnosis. J Inherit Metab Dis 16:568-570

IJlst L, Wanders RJA, Ushikubo S, Kamijo T, Hashimoto T (1994) Molecular basis of long-chain 3-hydroxyacyl-CoA dehydrogenase deficiency: identification of the major disease-causing mutation in the alpha-subunit of the mitochondrial trifunctional protein. Biochim Biophys Acta 1215:347-350

IJlst L, van Roermund CWT, Iacobazzi V et al (2001) Functional analysis of mutant human carnitine acylcarnitine translocases in yeast. Biochem Biophys Res Commun 280:700-706

Izai K, Uchida Y, Orii T, Yamamoto S, Hashimoto T (1992) Novel fatty acid beta-oxidation enzymes in rat liver mitochondria. I. Purification and properties of very-long-chain acyl-coenzyme A dehydrogenase. J Biol Chem 267:1027-1033

Kamijo T, Indo Y, Souri M et al (1997) Medium chain 3-ketoacylcoenzyme A thiolase deficiency: a new disorder of mitochondrial fatty acid beta-oxidation. Pediatr Res 42:569-576

Kler RS, Jackson S, Bartlett K et al (1991) Quantitation of acyl-CoA and acylcarnitine esters accumulated during abnormal mitochondrial fatty acid oxidation. J Biol Chem 266:22932-22938
Kolvraa S, Gregersen N, Christensen E, Hobolth N (1982) In vitro fibroblast studies in a patient with C6-C10- dicarboxylic aciduria: evidence for a defect in general acyl-CoA dehydrogenase. Clin Chim Acta 126:53-67

Kunau WH, Dommes V, Schulz H (1995) Beta-oxidation of fatty acids in mitochondria, peroxisomes, and bacteria: a century of continued progress. Prog Lipid Res 34:267-342

Law LK, Tang NL, Hui J et al (2007) A novel functional assay for simultaneous determination of total fatty acid beta-oxidation flux and acylcarnitine profiling in human skin fibroblasts using (2) $\mathrm{H}(31)$-palmitate by isotope ratio mass spectrometry and electrospray tandem mass spectrometry. Clin Chim Acta 382:25-30

Lehman TC, Thorpe C (1990) Alternate electron acceptors for medium-chain acyl-CoA dehydrogenase: use of ferricenium salts. Biochemistry 29:10594-10602

Lehman TC, Hale DE, Bhala A, Thorpe C (1990) An acyl-coenzyme A dehydrogenase assay utilizing the ferricenium ion. Anal Biochem 186:280-284

Luo MJ, He XY, Sprecher H, Schulz H (1993) Purification and characterization of the trifunctional beta-oxidation complex from pig heart mitochondria. Arch Biochem Biophys 304:266-271

Manning NJ, Olpin SE, Pollitt RJ, Webley J (1990) A comparison of $[9,10-3 \mathrm{H}]$ palmitic and $[9,10-3 \mathrm{H}]$ myristic acids for the detection of defects of fatty acid oxidation in intact cultured fibroblasts. J Inherit Metab Dis 13:58-68

Mashek DG, Bornfeldt KE, Coleman RA et al (2004) Revised nomenclature for the mammalian long-chain acyl-CoA synthetase gene family. J Lipid Res 45:1958-1961

McGarry JD, Brown NF (1997) The mitochondrial carnitine palmitoyltransferase system. From concept to molecular analysis. Eur J Biochem 244:1-14

Mitchell GA, Fukao T (2001) Inborn errors of ketone body metabolism. In: Scriver CR, Beaudet AL, Valle D, Sly WS (eds) The metabolic \& molecular basis of inherited disease. McGraw-Hill, New York, pp 2327-2356

Molven A, Matre GE, Duran M et al (2004) Familial hyperinsulinemic hypoglycemia caused by a defect in the SCHAD enzyme of mitochondrial fatty acid oxidation. Diabetes 53:221-227

Murthy MS, Kamanna VS, Pande SV (1986) A carnitine/acylcarnitine translocase assay applicable to biopsied muscle specimens without requiring mitochondrial isolation. Biochem J 236:143-148

Nada MA, Rhead WJ, Sprecher H, Schulz H, Roe CR (1995) Evidence for intermediate channeling in mitochondrial betaoxidation. J Biol Chem 270:530-535

Niezen-Koning KE, Wanders RJA, Nagel GT, IJlst L, Heymans HSA (1992) A new, simple assay for long-chain acyl-CoA dehydrogenase in cultured skin fibroblasts using stable isotopes and GCMS. Biochim Biophys Acta 1180:28-32

Niezen-Koning KE, Wanders RJA, Nagel GT, Sewell AC, Heymans HSA (1994) Measurement of short-chain acyl-CoA dehydrogenase (SCAD) in cultured skin fibroblasts with hexanoyl-CoA as a competitive inhibitor to eliminate the contribution of mediumchain acyl-CoA dehydrogenase. Clin Chim Acta 229:99-106

Oey NA, Ruiter JP, IJlst L et al (2006) Acyl-CoA dehydrogenase 9 (ACAD 9) is the long-chain acyl-CoA dehydrogenase in human embryonic and fetal brain. Biochem Biophys Res Commun 346:33-37

Olpin SE, Manning NJ, Carpenter K, Middleton B, Pollitt RJ (1992) Differential diagnosis of hydroxydicarboxylic aciduria based on release of $3 \mathrm{H} 2 \mathrm{O}$ from $[9,10-3 \mathrm{H}]$ myristic and $[9,10-3 \mathrm{H}]$ palmitic acids by intact cultured fibroblasts. J Inherit Metab Dis 15:883-890

Olpin SE, Manning NJ, Pollitt RJ, Clarke S (1997) Improved detection of long-chain fatty acid oxidation defects in intact cells using $[9,10-3 \mathrm{H}]$ oleic acid. J Inherit Metab Dis 20:415-419 
Palmieri F (2004) The mitochondrial transporter family (SLC25): physiological and pathological implications. Pflugers Arch 447:689-709

Pande SV, Brivet M, Slama A, Demaugre F, Aufrant C, Saudubray JM (1993) Carnitine-acylcarnitine translocase deficiency with severe hypoglycemia and auriculo ventricular block. Translocase assay in permeabilized fibroblasts. J Clin Invest 91:1247-1252

Pourfarzam M, Schaefer J, Turnbull DM, Bartlett K (1994) Analysis of fatty acid oxidation intermediates in cultured fibroblasts to detect mitochondrial oxidation disorders. Clin Chem 40:22672275

Rettinger A, Gempel K, Hofmann S, Gerbitz KD, Bauer MF (2002) Tandem mass spectrometric assay for the determination of carnitine palmitoyltransferase II activity in muscle tissue. Anal Biochem 302:246-251

Rhead WJ, Amendt BA, Fritchman KS, Felts SJ (1983) Dicarboxylic aciduria: deficient [1-14C]octanoate oxidation and mediumchain acyl-CoA dehydrogenase in fibroblasts. Science 221:73-75

Rinaldo P, Matern D, Bennett MJ (2002) Fatty acid oxidation disorders. Annu Rev Physiol 64:477-502

Schaefer J, Pourfarzam M, Bartlett K, Jackson S, Turnbull DM (1995) Fatty acid oxidation in peripheral blood cells: characterization and use for the diagnosis of defects of fatty acid oxidation. Pediatr Res 37:354-360

Schaefer J, Jackson S, Taroni F, Swift P, Turnbull DM (1997) Characterisation of carnitine palmitoyltransferases in patients with a carnitine palmitoyltransferase deficiency: implications for diagnosis and therapy. J Neurol Neurosurg Psychiatry 62:169176

Sim KG, Carpenter K, Hammond J, Christodoulou J, Wilcken B (2002) Acylcarnitine profiles in fibroblasts from patients with respiratory chain defects can resemble those from patients with mitochondrial fatty acid beta-oxidation disorders. Metabolism $51: 366-371$

Spiekerkoetter U, Sun B, Zytkovicz T, Wanders RJA, Strauss AW, Wendel U (2003) MS/MS-based newborn and family screening detects asymptomatic patients with very-long-chain acyl-CoA dehydrogenase deficiency. J Pediatr 143:335-342

Stanley CA, Hale DE, Coates PM et al (1983) Medium-chain acyl-CoA dehydrogenase deficiency in children with nonketotic hypoglycemia and low carnitine levels. Pediatr Res 17:877-884

Tajima G, Sakura N, Yofune H et al (2005) Enzymatic diagnosis of medium-chain acyl-CoA dehydrogenase deficiency by detecting 2-octenoyl-CoA production using high-performance liquid chromatography: a practical confirmatory test for tandem mass spectrometry newborn screening in Japan. J Chromatogr B Analyt Technol Biomed Life Sci 823:122-130

Tajima G, Sakura N, Shirao K et al (2008) Development of a new enzymatic diagnosis method for very-long-chain Acyl-CoA dehydrogenase deficiency by detecting 2-hexadecenoyl-CoA production and its application in tandem mass spectrometrybased selective screening and newborn screening in Japan. Pediatr Res 64:667-672

Taylor RW, Jackson S, Pourfarzam M, Bartlett K, Turnbull DM (1992) Measurement of acyl-CoA dehydrogenase activity in cultured skin fibroblasts and blood platelets. J Inherit Metab Dis 15:727-732 ter Veld F, Mueller M, Kramer S et al (2009) A novel tandem mass spectrometry method for rapid confirmation of medium- and very long-chain acyl-CoA dehydrogenase deficiency in newborns. PLOS ONE 4:e6449

Uchida Y, Izai K, Orii T, Hashimoto T (1992) Novel fatty acid betaoxidation enzymes in rat liver mitochondria. II. Purification and properties of enoyl-coenzyme A (CoA) hydratase/3-hydroxyacylCoA dehydrogenase/3-ketoacyl-CoA thiolase trifunctional protein. J Biol Chem 267:1034-1041

van Vlies N, Ruiter JPN, Doolaard M, Wanders RJA, Vaz FM (2007) An improved enzyme assay for carnitine palmitoyl transferase I in fibroblasts using tandem mass spectrometry. Mol Genet Metab 90:24-29

Ventura FV, IJlst L, Ruiter JPN et al (1998) Carnitine palmitoyltransferase II specificity towards beta-oxidation intermediatesevidence for a reverse carnitine cycle in mitochondria. Eur $\mathrm{J}$ Biochem 253:614-618

Ventura FV, Costa CG, Struys EA et al (1999) Quantitative acylcarnitine profiling in fibroblasts using [U-13C] palmitic acid: an improved tool for the diagnosis of fatty acid oxidation defects. Clin Chim Acta 281:1-17

Vianey-Saban C, Divry P, Brivet M et al (1998) Mitochondrial verylong-chain acyl-coenzyme A dehydrogenase deficiency: clinical characteristics and diagnostic considerations in 30 patients. Clin Chim Acta 269:43-62

Wanders RJA, Waterham HR (2006) Biochemistry of mamalian peroxisomes revisited. Annu Rev Biochem 75:295-332

Wanders RJA, IJlst L, Van Gennip AH et al (1990) Long-chain 3hydroxyacyl-CoA dehydrogenase deficiency: identification of a new inborn error of mitochondrial fatty acid beta-oxidation. $J$ Inherit Metab Dis 13:311-314

Wanders RJA, IJlst L, Poggi F et al (1992) Human trifunctional protein deficiency: a new disorder of mitochondrial fatty acid beta-oxidation. Biochem Biophys Res Commun 188:1139-1145

Wanders RJA, Vreken P, Den Boer MEJ, Wijburg FA, Van Gennip AH, IJlst L (1999) Disorders of mitochondrial fatty acyl-CoA beta-oxidation. J Inherit Metab Dis 22:442-487

Wanders RJA, Jansen GA, Lloyd MD (2003) Phytanic acid alphaoxidation, new insights into an old problem: a review. Biochim Biophys Acta 1631:119-135

Watkins PA (2008) Very long-chain acyl-CoA synthetases. J Biol Chem 283:1773-1777

Watmough NJ, Bhuiyan AKMJ, Bartlett K, Sherratt HSA, Turnbull DM (1988) Skeletal muscle mitochondrial beta-oxidation. A study of the products of oxidation of [U-14C]hexadecanoate by h.p.l.c. using continuous on-line radiochemical detection. Biochem J 253:541-547

Watmough NJ, Turnbull DM, Sherratt HSA, Bartlett K (1989) Measurement of the acyl-CoA intermediates of beta-oxidation by h.p.l.c. with on-line radiochemical and photodiode-array detection. Application to the study of [U-14C]hexadecanoate oxidation by intact rat liver mitochondria. Biochem J 262:261269

Yamaguchi S, Indo Y, Coates PM, Hashimoto T, Tanaka K (1993) Identification of very-long-chain acyl-CoA dehydrogenase deficiency in three patients previously diagnosed with long-chain acyl-CoA dehydrogenase deficiency. Pediatr Res 34:111-113 